\title{
Conceptualizing the Moderating Role of CEO Power and Ownership Concentration in the Relationship between Audit Committee and Firm Performance: Empirical Evidence from Pakistan
}

\author{
Sohail Ahmad Javeed ${ }^{1, *(\mathbb{D}}$, Tze San Ong ${ }^{2, *}$, , Rashid Latief ${ }^{3, *}$, Haslinah Muhamad ${ }^{2}$ and Wei Ni Soh ${ }^{2}$ \\ 1 Hangzhou College of Commerce, Zhejiang Gongshang University, Hangzhou 311500, China \\ 2 School of Business and Economics, Universiti Putra Malaysia, Serdang 43400, Malaysia; \\ hasm@upm.edu.my (H.M.); sohweini@upm.edu.my (W.N.S.) \\ 3 School of Finance and Economics, Jiangsu University, Zhenjiang 212013, China \\ * Correspondence: sohailahmaduaf@yahoo.com (S.A.J.); tzesan@upm.edu.my (T.S.O.); \\ rashidlatief@ujs.edu.cn (R.L.)
}

Citation: Javeed, S.A.; Ong, T.S.; Latief, R.; Muhamad, H.; Soh, W.N. Conceptualizing the Moderating Role of CEO Power and Ownership Concentration in the Relationship between Audit Committee and Firm Performance: Empirical Evidence from Pakistan. Sustainability 2021, 13, 6329.

https: / doi.org/10.3390/su13116329

Academic Editors: Marc A. Rosen and Ionel Bostan

Received: 24 January 2021

Accepted: 17 April 2021

Published: 3 June 2021

Publisher's Note: MDPI stays neutral with regard to jurisdictional claims in published maps and institutional affiliations.

Copyright: (c) 2021 by the authors. Licensee MDPI, Basel, Switzerland. This article is an open access article distributed under the terms and conditions of the Creative Commons Attribution (CC BY) license (https:// creativecommons.org/licenses/by/ $4.0 /)$.

\begin{abstract}
Firms in developing economies generally find ways to enhance their reputation and growth in the international market. In this context, an Audit Committee (AC) is composed of multiple skilled members that control and monitor auditing activities and present a transparent image of their firm, which automatically attracts investors and builds investor confidence. Therefore, this study used CEO power and ownership concentration as moderating factors to examine the connection between AC and firm performance. For this purpose, this study used the data of Pakistani manufacturing firms for the period 2008 to 2018 and applied the Ordinary Least Square (OLS) method, the Fixed Effect (FE) model, and the Generalized Method of Moments (GMM). To check the robustness of the results, this study used a Feasible Generalized Least Square (FGLS) model. The findings of this study contended that AC and firm performance have a positive association with each other. Moreover, the findings revealed that CEO power positively influenced firm performance. Furthermore, lower ownership concentration is a valuable approach to maximize a firm's performance. Importantly, the outcomes concluded that $\mathrm{AC}$ and firm performance have a positive connection with the moderating effects of CEO power. Moreover, $\mathrm{AC}$ and firm performance also have a positive association with the moderating effect of ownership concentration.
\end{abstract}

Keywords: audit committee; firm performance; ownership concentration; CEO power

\section{Introduction}

Fraudulent and non-transparent actions are key issues in developing economies because firms in these emerging countries are suffering from a deficiency of expert human resources related to accounting, financial, and other governance aspects [1]. Therefore, Khan et al. [2] stated that firm auditing practices are responsible for monitoring and controlling errors, frauds, and misleading information, and for revealing the truth. Audit committees (ACs) are one of the significant committees of company boards, which consist of skilled members in accounting and finance that oversee the financial activities of firms and their disclosure practices [3]. Prior studies focusing on the agency perceptions explored the idea that effectual ACs are an advantageous way to improve a firm's financial reporting $[4,5]$.

Furthermore, many scholars have examined the connections between ACs and firm performance, and the majority of studies concluded that positive connections exist [6-8], but few studies by contrast reported the existence of negative connections $[9,10]$. Apart from this, these investigators have not tried to explore the circumstances that create a positive or negative connection between $\mathrm{AC}$ and firm performance. Consequently, this 
study investigates major factors of corporate governance such as CEO power and ownership concentration as moderating factors that influence the connection between $\mathrm{AC}$ and firm performance.

Prior studies contended that it is important to investigate the effect of corporate governance measures implemented by top executives or management on the effectiveness of ACs [11-14]. Moreover, multiple studies reported that a powerful CEO and low ownership concentration are beneficial for ACs [15-17].

Using theoretical measures, agency theory reveals the association between principals and agents, which can be influenced by asymmetric information and augment agency costs; as a result of this association, $\mathrm{AC}$ is a valuable tool for reducing agency costs [18]. Consequently, forming an independent $\mathrm{AC}$ is an important approach for decreasing the asymmetric information between principals and agents. Furthermore, this theory also discourages self-interested behavior from agents through solid corporate governance mechanisms in the form of ACs or other board committees [19]. Moreover, firms with a high ownership concentration are positively associated with agency problems, and this issue can also be addressed with the help of an independent and skilled AC [20]. Furthermore, the managerial power theory and the organizational and management theory indicate that strong corporate governance in the form of CEO power and ownership concentration are essential for a strong overall performance and the performance of an AC [21-23].

In the context of developing economies, the formation of an AC is crucial for multiple reasons. For example, firms in developing economies suffer from a deficiency of skilled human resources in the form of a lack of skilled members who have exposure and expertise related to accounting and financial matters and other governance issues [24]. Furthermore, developing economies face multiple problems such as weak stock markets, unbalanced economic conditions, weak legal procedures and protections, and government interventions [25]. Furthermore, audit practices conducted in developing economies are untrustworthy because the majority of the firms in these countries have family ownership structures that can influence agents [26].

Developing economies such as Pakistan are associated with a higher concentrated ownership, which leads to the agency problem [26-28]. On the other hand, Siddiqui [29] reported that the industries of developing countries need to enhance their firms' reputations to attract shareholders and retain their confidence; thus, these firms should try to follow all international rules and standards related to accounting, finance, and corporate governance. These are the circumstances that motivated us to inspect the impact of auditing practices on firm performance and the role of corporate governance in the context of developing the economy.

Therefore, this investigation probes the connection between $\mathrm{AC}$ and firm performance. Thus, we used the key corporate governance factors of the CEO power and ownership concentration as moderating factors in the connection between $\mathrm{AC}$ and firm performance. To complete this investigation, we selected the Pakistani manufacturing firms and collected data for the period 2008 to 2018. For the analysis, we applied different statistical methods. Firstly, we employed the Ordinary Least Square (OLS) regression to determine the level of endogeneity in the panel data. Secondly, we employed the fixed effect model to control any unobservable heterogeneity. Thirdly, we employed the generalized method of moments (GMM) to control any endogeneity bias. To further validate the outcomes, we applied a feasible generalized least square (FGLS) method. This study found a positive linkage between AC and firm performance, as well as between CEO power and firm performance, ownership concentration, and firm performance. Moreover, this study largely concluded that $\mathrm{AC}$ and firm performance have a positive connection with the moderating role of $\mathrm{CEO}$ power and ownership concentration.

This study has several contributions to existing literature. Firstly, it highlights the importance of $\mathrm{CEO}$ power and $\mathrm{OC}$ for the audit committee $\mathrm{AC}$ ) and towards firm performance because prior studies only reported the positive or negative link between AC and firm performance without providing the reason. Prior to this study, there are no 
other studies that have examined the moderating role of CEO power and OC for the audit committee and towards firm performance. Secondly, it plays an imperative role in the scope of auditing practices. Thirdly, these outcomes contribute to the literature by extending the agency theory and organizational and management theory as a piece of evidence about the importance of the $\mathrm{AC}$, as well as the major elements of corporate governance for minimizing agency dispute. Fourthly, this study sheds light on the importance of CEO power and ownership concentration for AC to improve firm performance. Fifthly, this study encourages the role of independent $\mathrm{AC}$ for improving auditing practices in both developed and developing economies. Sixthly, this study also highlights the role of expert auditors in the improvement of auditing. Additionally, this study encourages all stakeholders to be involved in transparent practices for higher profits and concludes that financial transparency is a major cause to improve business performance. This study suggests to the GOP and SECP to make it mandatory for top executives of corporations to control and monitor auditing practices. This study gives direction to law-formulating institutions to formulate strict regulations that can improve transparency at the firm level.

This study is classified into different sections: Section 2 shows the auditing practices in Pakistan; Section 3 reveals the theoretical and empirical literature and hypothesis development; Section 4 shows the data collection method, econometric models, and statistical techniques; Section 5 reveals the results and discussion; and lastly, Section 6 presents the conclusion and policy implications. Figure 1 exhibits the conceptual framework for this study.

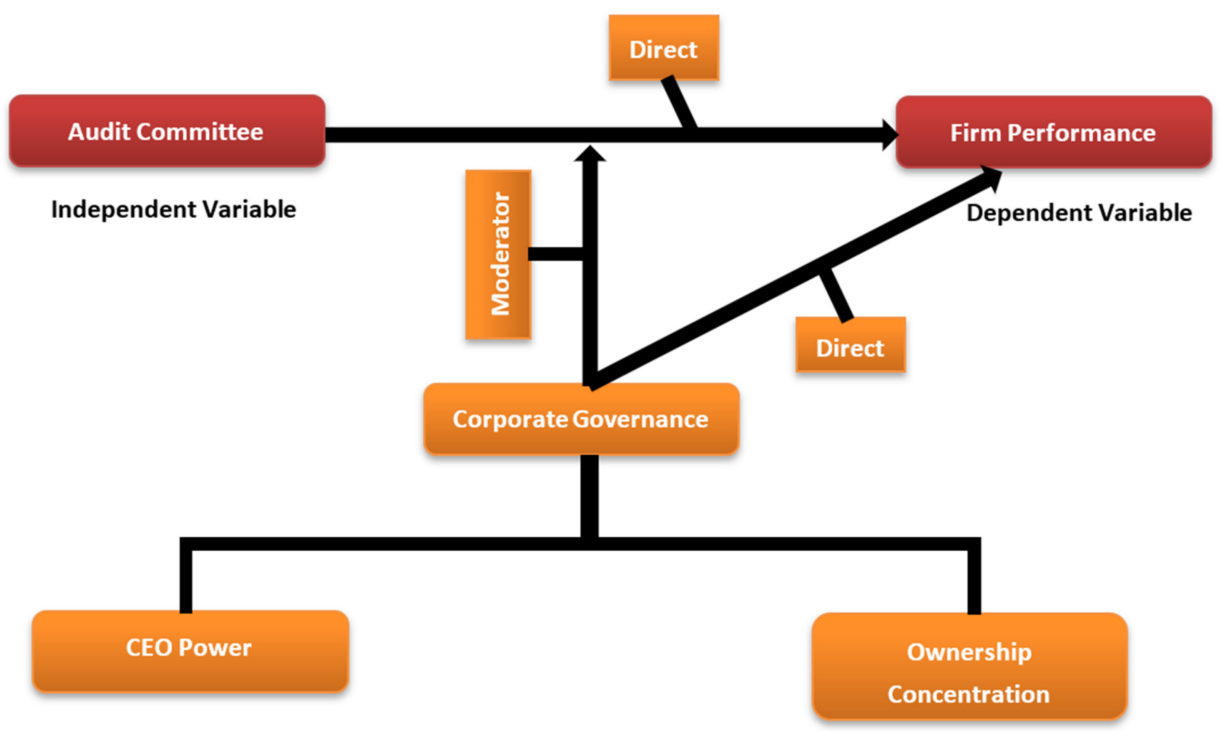

Figure 1. Conceptual framework.

\section{Auditing Practices in Pakistan}

Pakistan is a developing country with various issues such as political instability, corruption, and weak law promulgation [30,31]. Moreover, Ibrahim [32] contended that corporate governance practices in Pakistan are very poor; therefore, the Securities and Exchange Commission of Pakistan (SECP) should focus on this issue and strengthen the corporate governance mechanism. Moreover, Shah and Butt [33] stated that the majority of Pakistani firms have concentrated ownership, which thus leads to the inefficiency of corporate boards.

Nevertheless, the SECP has presented a corporate governance code with the assistance of the World Bank and International Monetary Funding (IMF) to manage and enhance corporate governance practices [31,34]. This code, in line with the international accounting rules and regulations, has various implications for Pakistani firms to develop transparent financial and non-financial reporting, executives' compensation strategy, and policies for ownership structure. Furthermore, this code also sheds light on the formation of an AC 
and the independence of auditors for better transparency. This code mentions that an AC can recommend the internal auditor for one year, and the subsequent extension will then be based on performance [35].

Rustam et al. [36] argued that an AC is a valuable sub-committee of the board that plays an imperative part in the improvement of audit quality. Additionally, this corporate governance code explained that the AC not only assists the board of directors, but also highlights the shareholders' rights. This code states that the formation of the AC is the responsibility of the board of directors with a minimum of three members and that one member should be an independent director. This AC mainly focuses on the monitoring of financial reporting and auditor activities in order to make firm actions transparent. It is the major responsibility of the $\mathrm{AC}$ to have a meeting and discussion with the executives of the audit department quarterly in a financial period. However, the board of directors is still accountable in examining the efficiency of the AC and present it to the shareholders of firms.

Therefore, various researchers reported that Pakistan is a country that has a good capital market, and its majority regulations focus on investor safety and protection [37,38]. Yusuf et al. [39] highlighted that the capital market of Pakistan has unique characteristics that encourage social and environmental activities compared to developed economies.

\section{Theoretical Background and Review of the Literature}

\subsection{Audit Committee and Firm Performance}

The owners and managers working in the same organization may have some disputes about asymmetric information and agency cost. In this context, the agency theory reports that these conflicts can be minimized or reduced by providing incentives to managers for limited work of self-interest [18,20]. Bonazzi and Islam [40] contended that the principal with the help of incentives can monitor the activities of agents and reduce self-interest behaviors. Thus, there is a need to develop a strong corporate governance mechanism in order to minimize such behaviors among the agents by developing independent audit committees or other board committees [19]. An AC is a valuable approach to minimize asymmetric information between owners and management because an independent AC focuses on the organization's transparent actions, which in turn builds the confidence between owners and managers [19].

The important initiative for the composition of the Audit Committee (AC) as a subcommittee of the board was discussed in Smith's report published in 2003 in the UK [41]. It is stated that the $\mathrm{AC}$ is responsible for conducting independent audits and monitoring both internal and external auditors for transparency. The AC also ensures that all audit activities performed by the internal auditor are true and fair, in line with the organization's rules and regulations, accounting standards, financial rules, etc. [41]. Moreover, the AC provides a guarantee to the external auditor for their independence. Generally, an AC consists of independent directors, who have multiple benefits such as no pressure from the management or other parties, and normally, a higher audit quality is connected with the independence of the auditor [42].

Chan and $\mathrm{Li}$ [43] contended that independent directors in an AC focus on the firms' financial operations, which subsequently minimize the chances of frauds and improve firm performance. Aldamen, Duncan, Kelly, McNamara, Nagel and Finance [6] stated that an AC is a profitable approach to augment the firm performance, and good corporate governance is imperative for the implementation of an AC. In the Pakistani context, Arshad et al. [44] discovered that the AC not only improves firm performance, but also enhances the firm's reputation in the market. Rustam, Rashid and Zaman [36] provided empirical evidence about the benefits of an AC for audit fees and incentives in Pakistan. They concluded that an $\mathrm{AC}$ is valuable for audit fees, and it provides incentives to the management, which encourage them to play a significant role in auditing practices. In addition, Kallamu and Saat [45] in Malaysia highlighted that the AC has multiple attributes such as detection 
and correction of errors and frauds, monitoring the financial activities of the firm, and controlling the management to perform fair tasks.

On the contrary, Zhou, Owusu-Ansah, Maggina and Taxation [10], who investigated the importance of the $\mathrm{AC}$ and board of directors for firm performance in Greece, suggested that the AC is not advantageous for firm performance. Bansal and Sharma [46] also reported that corporate governance is associated with higher profit, but the AC does not improve the firm performance. The AC may only affect the firm internal auditing by applying pressure, which in turn leads to lower profitability [47]. Furthermore, various scholars have provided empirical evidence that confirmed the negative association between AC and firm performance [48]. As the empirical literatures have shown mixed evidence about the connection between $\mathrm{AC}$ and firm performance, we have thus developed the following hypothesis based on the above agency theory and the previous literature:

Hypothesis H1. The audit committee has a significant and positive effect on firm performance.

\subsection{CEO Power and Firm Performance}

Corporate governance is a major element for every firm. A CEO is considered the most powerful entity in the corporate governance mechanism and may affect a firm's policy making. Therefore, multiple theories have developed a theoretical base to inspect the role of CEO power in firm performance. For example, according to the economic theory, a powerful CEO may create disputes among shareholders and managers, which will consequently create agency problems, and the agency theory also reported that a powerful $\mathrm{CEO}$ is not good for firm performance because it may increase the agency cost [20]. A powerful CEO is not beneficial because they may be overconfident and ignore the opinion of the other executives, which will result in a fallout in sub-optimal decision making [49].

Multiple scholars have reported that a powerful CEO is not valuable for firm performance [50-53]. Bebchuk, Cremers and Peyer [52] explained that CEO power reduces firm performance because of the agency problem. Similarly, Landier et al. [54] also contended that a powerful CEO is harmful to firm performance by implanting forceful decisions without the consent of other executives.

In contrast, efficiency theory states that a CEO must be powerful; the advantages of a powerful CEO are more than agency cost [55]. A powerful CEO holds the main decisionmaking power and controls the management to perform better and follow the instructions of the CEO [56]. Apart from that, organizational and management theory demonstrates that a powerful CEO is beneficial for firm value [21]. Generally, firms in developing economies are held by family members, and they struggle hard for the maximization of profit [31]. Similarly, managerial power theory also supports powerful CEOs, as a CEO with higher compensation positively affects the FP [22].

Berger et al. [57] reported that firms' innovational activities normally depend on CEO decision making, and the CEO has the major decision power. Papadakis [58] stated that shareholders consider the CEO the leader to enhance firm value. Coles et al. [59] discovered industrial tournament incentives as CEO power and reported that a powerful CEO is valuable for firm value, as well as to reduce firm risk and make investment and financial policies. Apart from being a job, a CEO in developing countries such as Pakistan is assumed as most powerful because this position is mainly held by a family member $[60,61]$. A powerful CEO wants to manage his status and reputation by putting all efforts into improving firm performance [62,63]. Sheikh [23] found that a CEO with power is more concerned with firm value and strictly monitors the efficiency of the management for the enhancement of firm performance.

Based on prior literature, there is mixed evidence about the connection between CEO power and firm performance, which leads to a research gap. However, a majority of the studies support the positive connection between CEO power and firm performance [21,22]. Therefore, we have developed the following hypothesis by following the above empirical and theoretical evaluation: 
Hypothesis H2. A powerful CEO positively influences firm performance.

\subsection{Ownership Concentration and Firm Performance}

After the CEO, ownership concentration is crucial in corporate governance, as it plays a key role in corporate governance [64]. Generally, ownership concentration involves policy making, decision making, and improvement of the organization's activities. Therefore, ownership concentration is an imperative tool to enhance firm performance. The ownership structure generally plays a role to minimize asymmetric information in capital markets between outsiders and insiders [65]. The managerial power theory explains the importance of ownership structure for firm performance [50] as having a positive effect. This is because ownership structure is an imperative approach to minimize agency costs by involving management in the ownership of the shares [20]. Therefore, large shareholders with power provide incentives to the management for working effectively and efficiently.

Berle and Means [66] stated that ownership concentration refers to the ratio of large shareholders, and these shareholders are interested in enhancing their wealth. Ownership concentration is an imperative means because it involves preventing illegal or misused activities of minor shareholders [17]. The Pakistani markets are extremely concentrated due to family ownership [67]. Abbas et al. [68] discovered that ownership concentration in Pakistan plays a significant role in enhancing firm performance because of family ownership. Moreover, Peng and Yang [69] reported that larger shareholders participate in a policy making and find ways to enhance profit for firms in the long run.

Large shareholders align the interest of management and minor shareholders for reducing agency cost, which automatically enhances firm profit [70]. Empirically, Hanousek et al. [71] revealed that concentrated ownership has a positive influence on firm performance. Omran [72] selected 52 Egyptian firms to study the connection between ownership concentration and firm performance and concluded that both have a positive relationship. Ownership concentration derives mainly from legal protection in order to protect shareholders and registered firms in the stock markets of countries with weaker legal protection [73]. In addition, Yasser and Mamun [74] also investigated the connection between ownership concentration and firm performance in Pakistan. It is shown that firm performance can be enhanced by ownership concentration. Developing countries have high ownership concentration and family ownership as compared to developed countries $[27,28]$.

Therefore, we have developed the following hypothesis based on the above empirical and theoretical evaluation:

Hypothesis H3. Ownership concentration positively influences firm performance.

\subsection{The Moderating Role of CEO Power}

The involvement of corporate governance in the board and audit committees enhances firm financial reporting, as well as audit quality [11,75]. Abbott and Parker [76] and Boyd et al. [77] reported that corporate governance has a major responsibility in establishing an independent $\mathrm{AC}$ for the improvement of audit quality. Thus, a powerful CEO is a major factor in the corporate governance mechanism of firms.

Previous auditing studies revealed that asymmetric information is the cause for supply and demand that brought audit mediocrity $[78,79]$. Thus, agency theory is beneficial for reducing the conflicts between managers and owners or information asymmetry [20]. The principal wants to recruit independent auditors for better quality and reduction of errors and frauds. Therefore, the auditor must ensure that all auditing procedures are being followed when the $\mathrm{CEO}$ has power [80]. Furthermore, organizational and management theory states that a powerful CEO tries to enhance the firm performance and reputation in order to maintain the status of the firm in the market [22]. The prior literature reveals that firm reputation in the form of financial reporting and audit quality can be improved with an independent $\mathrm{AC}[75,81]$. 
As a result, a powerful CEO formulates an independent $\mathrm{AC}$ to assure the shareholders and investors that all financial and non-financial practices are transparent and free from errors. Moreover, a strong governance with CEO power enhances firm transparency in the form of financial reporting and firm dealings $[15,16]$. A powerful or family member CEO is valuable for firm performance and transparency in the context of audit quality [82].

Jizi and Nehme [83] evaluated the association between audit fees and board independence with the moderating effects of CEO duality in US banks and found that both have a positive association with the moderating effects of CEO duality. Karim et al. [84] probed the relationship between CEO power, board ownership, and auditor quality in Bangladesh. After employing logistic regression, they found that CEO power has a positive connection with audit quality, while board ownership has a negative connection with audit quality.

Lisic et al. [85] argued that CEO power is a beneficial way to reduce the negative effects of $\mathrm{AC}$ and firm internal control issues. They further contended that a CEO with less power has negative effects on the connection between $\mathrm{AC}$ and firm internal governance. In addition, Kim et al. [86] also uncovered that a powerful CEO has a major role in formulating the AC with financial experts and managing the audit fees. Alzeban [87] stated that a powerful CEO is extremely crucial for the quality of financial reporting and monitoring of auditor tasks. Furthermore, Tee [88] investigated the association of CEO power with audit fees in Malaysia and found that a powerful CEO is more concerned with audit quality and reduces audit fees.

Based on prior literature, it has been revealed that CEO power has a positive connection with firm performance $[58,59,62,63]$. Therefore, we have developed the following hypothesis by following the above empirical literature and agency theory:

Hypothesis H4. A Powerful CEO significantly moderates the positive relationship between the audit committee and firm performance.

\subsection{The Moderating Role of Ownership Concentration}

Shleifer and Vishny [17] contended that ownership concentration is a valuable tool to reduce or prevent illegal practices and fraud for minor shareholders. Normally, agency issue arises between managers and owners because of asymmetric information in firms that hold ownership concentration [20]. The situation of agency issue applies to the firms that have ownership concentration. This is because major shareholders may use funds for their best interests despite caring for the minor shareholders. Due to the different interests between management and shareholders, asymmetric information is usually available in the capital market. Thus, this situation demands independent and quality audits of the financial statement of the firm, and this can be possible only with an independent audit committee. Jensen and Meckling [20] and Imhoff [89] stated that an external or independent audit provides confidence to the shareholders that all financial activities are based on fair tasks.

However, agency theory suggests that disputes are obsessed with extensively discrete ownership and the isolation between management and shareholders. In this context, Watts and Zimmerman [90] stated that disputes between management and shareholders enhance the demand for a higher quality audit.

Furthermore, scholars reported that management demands high quality of audits when a firm has ownership concentration [91]. Lin and Liu [92] investigated the role of ownership concentration on audit quality in China and found that firms with ownership concentration are more willing to pay higher fees for a quality audit. Srinidhi, He and Firth [79] evaluated auditor choice in the US family-based firms and concluded that firms that have better governance boards are more interested in appointing an expert auditor for the audit quality.

In addition, Fan and Wong [93] provided evidence that family firms in East Asian countries are more interested in paying higher fees for audit quality. Similarly, Wahab et al. [94] highlighted the importance of corporate governance for audit quality and stated that larger 
shareholders are interested in developing an AC for transparent reporting. Mustapha and Che Ahmad [95] contended that blockholders are more concerned with monitoring the audit quality and executive remuneration in Malaysia.

Nevertheless, the previous literature has revealed that audit quality enhances firm performance, and ownership concentration is also valuable for firm performance (Arshad, Satar, Hussain, and Naseem [44]; Berle and Means [76,77]; Abbas, Naqvi, and Mirza [79]; Peng and Yang [80]). According to Hussain [26], Pakistani firms have a large ratio of ownership concentration. They reported that most businesses or firms are run by family ownership in Pakistan. Their results also revealed that $87 \%$ of companies are owned by the controlling shareholders in Pakistan. Shleifer and Vishny [17] stated that corporate governance mechanism could be improved by larger concentrated ownership and the legal safety of investors. Therefore, there is a need to look into the Pakistani market and inspect the association between $\mathrm{AC}$ and firm performance when firms have a higher ratio of ownership concentration. Consequently, we have developed the following hypothesis based on the above empirical literature and agency theory:

Hypothesis H5. The audit committee has a positive connection with firm performance while moderating the effects of ownership concentration.

\section{Sample and Empirical Approaches}

\subsection{Sample Size}

This study is based on the Pakistani manufacturing sector, which is further comprised of 16 sub-sectors from the Pakistan Stock Exchange (PSX). These sub-sectors include textile weaving, woolen, textile composite, chemical, cement, fertilizer, oil and gas marketing, pharmaceutical, transport, synthetic and rayon, automobile assembler, engineering, cable and electrical goods, automobile parts and accessories, oil and gas exploration, and refinery. These sectors consist of 242 firms in total, but those firms for which data were missing in their annual reports were excluded. Apart from that, firms from the sample that were declared as the defaulter or bankrupt by the PSX were also excluded. Finally, we selected only those firms that were registered before 2008 with outstanding shares of 100 million rupees. The corporate governance practices in Pakistan were developed in 2002, but only received a higher response from firms in 2008 after the financial crisis [96]. Before 2007, the firms in Pakistan were not fully involved in corporate governance practices and did not properly disclose the data, but major firms eventually started the corporate governance practices in 2008 by following the SECP guidance [97]. This study selected the sample period after 2008 because the data were fully available for this period of time, and the SECP codes for corporate governance were properly implemented after 2008 in Pakistan. Furthermore, corporate governance practices are not fully developed in Pakistan and only large and old firms are involved in these practices. Javeed and Lefen [98] discovered that large firms in Pakistan have higher involvement in corporate governance practices than small firms. Moreover, small firms are not officially registered in the PSX [99]. Considering this criterion, we excluded 95 firms and focused on the 147 firms for this study. Table 1 shows the firms' selection process. Multiple sources have been used to collect this data such as PSX, SECP, firms' annual reports, and State Bank of Pakistan (SBP) from 2008 to 2018.

Various causes motivated us to focus on the Pakistani manufacturing sector for this study. Firstly, Indicators [100] reported that the export ratio of manufacturing firms is higher than other sectors in Pakistan, and therefore, we believe that firms of developing economies have exposure to international market rules and standards while involving in export activities. Secondly, Ehsan et al. [101] concluded that manufacturing firms of Pakistan are involved in more information disclosure and transparency activities as compared to other sectors. Thirdly, Wang and Chui [102] contended that manufacturing firms are normally involved in the production process and equipped with big resources and there are thus more chances of errors and frauds. In this aspect, there is a need to look into the manufacturing firms' audit matters. Next, Pakistani manufacturing firms follow 
all standards for auditing and accounting matters compared to firms in other sectors [103]. In addition, the auditing practices of manufacturing firms are positively linked with the business performance in Pakistan [7]. Moreover, they reported that the Pakistani market is highly concentrated, and manufacturing firms perform proper auditing practices in line with international standards. Additionally, the stakeholders are highly involved in monitoring the disclosure practices of manufacturing firms in Pakistan [104].

Table 1. Firm selection.

\begin{tabular}{|c|c|c|c|c|c|}
\hline Sr. No. & Sectors & $\begin{array}{l}\text { No. of } \\
\text { Firms }\end{array}$ & $\begin{array}{l}\text { Dropped } \\
\text { Firms }\end{array}$ & Reasons for Dropping Firms & $\begin{array}{l}\text { Final Selection } \\
\text { of Firms }\end{array}$ \\
\hline 1 & Textile Weaving & 9 & 4 & Declared Defaulter by PSX & 5 \\
\hline 2 & Textile Composite & 58 & 23 & Declared Defaulter by PSX and Data Missing & 35 \\
\hline 3 & Textile Woolen & 4 & 1 & Declared Defaulter by PSX & 3 \\
\hline 4 & Cement & 25 & 8 & Declared Defaulter by PSX and Data Missing & 17 \\
\hline 5 & Chemical & 29 & 6 & Declared Defaulter by PSX & 23 \\
\hline 6 & Fertilizer & 9 & 6 & Declared Defaulter by PSX & 3 \\
\hline 7 & Transport & 7 & 4 & Declared Defaulter by PSX & 3 \\
\hline 8 & $\begin{array}{l}\text { Oil and Gas } \\
\text { Marketing }\end{array}$ & 11 & 5 & Declared Defaulter by PSX and Data Missing & 6 \\
\hline 9 & Pharmaceutical & 12 & 4 & Declared Defaulter by PSX and Data Missing & 8 \\
\hline 10 & $\begin{array}{l}\text { Synthetic and } \\
\text { Rayon }\end{array}$ & 13 & 5 & Declared Defaulter by PSX & 8 \\
\hline 11 & $\begin{array}{l}\text { Automobile } \\
\text { Assembler }\end{array}$ & 16 & 4 & Declared Defaulter by PSX & 12 \\
\hline 12 & Engineering & 20 & 12 & Declared Defaulter by PSX and Data Missing & 8 \\
\hline 13 & $\begin{array}{c}\text { Cable and } \\
\text { Electrical Goods }\end{array}$ & 9 & 4 & Declared Defaulter by PSX & 5 \\
\hline 14 & $\begin{array}{l}\text { Automobile Parts } \\
\text { and Accessories }\end{array}$ & 11 & 6 & Declared Defaulter by PSX & 5 \\
\hline 15 & $\begin{array}{l}\text { Oil and Gas } \\
\text { Exploration }\end{array}$ & 5 & 1 & Declared Defaulter by PSX & 4 \\
\hline 16 & $\begin{array}{l}\text { Refinery } \\
\text { Total Firms }\end{array}$ & $\begin{array}{c}4 \\
242\end{array}$ & $\begin{array}{c}2 \\
95\end{array}$ & Declared Defaulter by PSX & $\begin{array}{c}2 \\
147\end{array}$ \\
\hline
\end{tabular}

Manufacturing firms in Pakistan have large family ownership. Therefore, researchers believe that they may be involved in the tampering of auditing practices [105]. In addition, corporate governance practices are crucial in manufacturing firms, which requires the researchers to look into these practices [106]. Finally, the productivity of manufacturing firms is higher compared to the firms in the other sectors [107]. Gill and Biger [108] concluded that working efficiency and corporate governance practices are much better in manufacturing firms compared to the firms in other sectors. Javeed and Lefen [99] also revealed that manufacturing firms are highly involved in following the international accounting rules and standards than the firms in the other sectors in Pakistan. Moreover, for the last 20 years, the request from stakeholders for transparency has been enhanced, especially for the firms in the manufacturing sector because these firms have higher involvement in using raw materials, technology, and production. Therefore, there are higher chances of fraud in manufacturing firms.

\subsection{Variables Measurement}

\subsubsection{Firm Performance}

The ultimate intention of every business or firm is to stimulate the firm's performance. Firms' financial performance has been used as a dependent variable in this study. Florax et al. [109] stated that the appropriate calculation of the variables is important for finding acceptable outcomes in the field of corporate governance. For instance, Kim and Rasiah [110] reported multiple means to determine firm performance, return on equity, earning per share, return on asset, and productivity. In this context, Shen et al. [111] 
discovered that return on asset (ROA) is a superior approach to determining accountingbased firm performance. To support this, Hutchinson and Gul [112] and Bhagat and Bolton [113] also presented that ROA shows the management efficiency and accuracy for firm performance. Thus, it is supposed to be a valuable technique compared to the other accounting-based methods. Consequently, we first used ROA as the dependent variable in this study and determined it as net profit to the net asset [114-116].

Ciftci et al. [117] contended that one or a single dimension may be distrustful. Therefore, this study relies on another measurement that is based on market performance. Wagner [118] revealed that the firm market-based calculation is a valuable source to examine the growth and opportunities of the firm. The majority of the studies relied on Tobin's $Q$ for measuring the firm's market-based performance [117-120]. Thus, this study determined Tobin's $Q$ as the market value of the firm (equity and debt) to the total asset of the firm [117-120].

\subsubsection{Audit Committee}

Aldamen et al. [6] stated that the AC is referred to as a committee that consists of non-executive directors whose purpose is to monitor the audit activities in the firm. Arens et al. [121] explained that the experts selected by the board of directors are to monitor and improve audit quality. Various scholars developed multiple ways to determine the AC variable at a firm level. An example is Aldamen, Duncan, Kelly, McNamara and Nagel [6] who used AC total members, AC meetings, the ratio of independent directors on an AC, etc. Similarly, Hamdan et al. [122] measured the AC as size, independent directors, $\mathrm{AC}$ activities, and experts on an AC. Therefore, it is imperative to calculate the accurate measurement of the AC that reflects the Pakistani market characteristics. For instance, the corporate governance code of Pakistan has forced firms to have an AC as a sub-committee of the board, and it must have one independent director in the AC [34]. For this, we have used two measures for the AC in the Pakistani context, which are (1) the ratio of independent directors in an $\mathrm{AC}$ and (2) the size of the AC [10,45].

\subsubsection{Chief Executive Officer (CEO) Power}

Chief Executive Officer (CEO) is supposed to be the key authority in a firm for decision- and policy-making purposes [123]. In this study, we used CEO power as a moderating variable, measured with the $\mathrm{CEO}$ compensation ratio in line with previous studies [99,124]. Structural power is used as CEO power, which is computed as CEO's entire compensation divided by board of directors and other top management's compensations. Cash compensation is the best tool to conduct the CEO power in firms [124]. Javeed and Lefen [99] also used the same measure to examine the moderating role of CEO power for corporate social responsibility and firm performance.

\subsubsection{Ownership Concentration}

This study has used ownership concentration measured by major shareholding portion or top five shareholders to study the association with firm performance $[125,126]$.

\subsubsection{Control Variables}

Control variables have an imperative role in empirical studies, especially for corporate finance literature [127]. Generally, control variables provide support to main variables [128]. The appropriate selection of control variables may authenticate the actual outcomes [129]. Therefore, various control variables have been used to support this study: firstly, this study determined firm size (FS) with the help of the natural log of assets [130]. Firm size is the most important control variable in the empirical finance literature [127]. Moreover, the results of the firm size variable change according to the firm structure [131]. Secondly, this study considered that the Audit Committee Expertise (ACE) is a valuable control variable for this study and calculated it as the total number of financial experts serving on the audit committee [132]. This study investigates the linkage of auditing practices with firm 
performance, and ACE is an imperative control variable to support the main model of this study [7]. Al-Matari et al. [133] highlighted that the audit committee size plays a vital role in the improvement of firm performance.

Next, this study used leverage (Lev) and determined it as total liabilities divided by the total assets [134]. Ibhagui et al. [135] supported the role of leverage for improving firm performance and auditing [9]. Aside from that, this study used asset turnover (AT) as a control variable and measured it as the total sale to total asset [136]. To support this variable for auditing, Chen et al. [136] revealed that asset turnover and auditing are positively associated in corporate finance studies. Lastly, this study measured property, plant, and equipment (PPE) as the net amount of plant, property, and equipment divided by total sales [131]. PPE plays a role in controlling the independent and dependent variables in empirical corporate finance studies [137]. The selection of these three control variables is highly important for this study because prior studies revealed the significant support of these variables $[7,99]$. Table 2 reveals the construction of the variables.

Table 2. Variable construction.

\begin{tabular}{|c|c|c|}
\hline Variable Names & Abbreviations & Measures \\
\hline \multicolumn{3}{|r|}{ Dependent Variables } \\
\hline Return on Asset & ROA & Net profits/Total assets $[114,116]$. \\
\hline Tobin's Q & TQ & The market value of firm/Firm total assets value [118,119]. \\
\hline \multicolumn{3}{|r|}{ Independent Variables } \\
\hline Audit Committee & $\mathrm{AC} 1$ & The ratio of the independent directors in the audit committee [6]. \\
\hline Audit Committee & AC2 & Total number of directors serving in audits committee [122]. \\
\hline Chief Executive Officer Power & $\begin{array}{c}\text { CEO } \\
\text { Power }\end{array}$ & CEO annual compensations / Whole board of directors compensations [138]. \\
\hline Ownership Concentration & OC & The major shareholding portion or Top 5 shareholders [125]. \\
\hline \multicolumn{3}{|r|}{ Control Variables } \\
\hline Firm Size & FS & The natural log of total assets [130]. \\
\hline Audit Committee Expert & $\mathrm{ACE}$ & Financial expert members in audit committee [122]. \\
\hline Leverage & LEV & Total liability divided by total assets [133]. \\
\hline Asset Turnover & ATO & The ratio of total sales to the total asset [135]. \\
\hline Property, Plant, and Equipment & PPE & Amount of plant, property, and equipment divided by total sales [130]. \\
\hline
\end{tabular}

\subsection{Estimation Procedure}

According to prior researchers, panel data in the field of corporate governance carry endogeneity problems $[113,139]$. However, when a majority of scholars studied panel data, almost $90 \%$ of the scholars failed or were not interested in exploring the endogeneity problems (e.g., $[140,141])$. Therefore, we believe that it is compulsory to find out the endogeneity issue in the panel data and apply appropriate methods to control it. One such method is the Ordinary Least Square (OLS) regression, which is supposed to be a valuable technique to find the relationship between dependent and independent variables. We employed OLS regression for each equation in order to identify the endogeneity bias in panel data by using the Durbin-Wu-Hausman test in line with previous studies [142-144].

Additionally, the panel data sometimes have unnoticeable heterogeneity due to stringent endogeneity, which can be explained as predicted and explanatory variables that have no effect on each other [142-144]. However, an OLS model is not suitable to solve the unnoticeable heterogeneity. Therefore, this study employed the fixed effect model based on the Hausman test to cover the unobservable heterogeneity in line with previous studies [143,144]. 
This study also used the generalized method of moments (GMM) to cover the endogeneity issues along with lagged control as instruments, as the GMM or other dynamic model is a more suitable model than other models to deal with the endogeneity issue $[130,133,144]$.

\subsection{Model Construction}

We have developed the following models to empirically examine the connection between the $\mathrm{AC}$ and firm performance with the moderating role of ownership concentration and CEO power:

$$
\begin{gathered}
Y_{i, t}=\alpha_{1}+\beta_{1} X_{1 i, t}+\gamma_{1} Z_{i, t}+\mu_{i, t} \\
Y_{i, t}=\alpha_{2}+\beta_{2} X_{2 i, t}+\gamma_{2} Z_{i, t}+\mu_{i, t} \\
Y_{i, t}=\alpha_{3}+\beta_{3} X_{3 i, t}+\gamma_{3} Z_{i, t}+\mu_{i, t} \\
Y_{i, t}=\alpha_{4}+\beta_{4} X_{1 i, t}+\beta_{5} X_{2 i, t}+\beta_{6} X_{1 i, t} \times X_{2 i, t}+\gamma_{4} Z_{i, t}+\mu_{i, t} \\
Y_{i, t}=\alpha_{5}+\beta_{7} X_{1 i, t}+\beta_{8} X_{3 i, t}+\beta_{9} X_{1 i, t} \times X_{3 i, t}+\gamma_{5} Z_{i, t}+\mu_{i, t}
\end{gathered}
$$

These equations reveal the models for the investigation between the audit committee and firm performance with the moderating effects of CEO power and ownership concentration. $Y_{i, t}$ is the dependent variable of firms $i$ and year $t$ in Equations (1)-(5) and examined as ROA and Tobin's $Q$ by developing two alternate equations for each model. $X_{1 i, t}$ is the audit committee, which is measured as $\mathrm{AC}_{1}$ and $\mathrm{AC}_{2} . X_{2 i, t}$ is the $\mathrm{CEO}$ power, and $X_{3 i, t}$ reveals the ownership concentration (OC). $X_{1 i, t} \times X_{2 i, t}$ is the interaction between the audit committee (AC) and CEO power (CEO power) of firms $i$ and year $t . X_{1 i, t} \times X_{3 i, t}$ is the interaction between the audit committee (AC) and ownership concentration (OC) of firms $i$ and year $t . Z_{i, t}$ is the control variable in all models of firms $i$ and year $t . \mu_{i, t}$ is the error term in all models of firms $i$ and year $t . \alpha_{1}$ to $\alpha_{5}$ reveal the constant term. $\beta_{m}, \gamma_{n}$ is the constant terms to be estimated; $m=1,2,3,4,5,6,7$.

\begin{tabular}{|c|c|c|c|c|c|c|c|c|c|c|c|c|c|}
\hline Variables & M & SD & 1 & 2 & 3 & 4 & 5 & 6 & 7 & 8 & 9 & 10 & 11 \\
\hline 1. ROA & 0.164 & 0.208 & 1 & & & & & & & & & & \\
\hline 2. TQ & 0.033 & 0.048 & $0.98 * * *$ & 1 & & & & & & & & & \\
\hline 3. $\mathrm{AC}_{1}$ & 1.686 & 0.746 & $0.14^{* * *}$ & $1.17^{* * *}$ & 1 & & & & & & & & \\
\hline 4. $\mathrm{AC}_{2}$ & $\begin{array}{l}1.0000 \\
0.030\end{array}$ & 0.136 & $0.26^{* * * *}$ & $0.27 * * *$ & $-0.17 * * *$ & 1 & & & & & & & \\
\hline 5. CEO Power & 0.693 & 0.369 & $0.25 * * *$ & 0.30 **** & $0.89 * * *$ & $-0.11^{* * * *}$ & 1 & & & & & & \\
\hline 6. OC & 0.061 & 0.029 & $0.26^{* * *}$ & $0.26^{* * *}$ & $-0.18 * * *$ & $0.99 * * *$ & $-0.13 * * *$ & 1 & & & & & \\
\hline 7. ATO & 8.26 & 5.79 & $0.11 * * *$ & $0.09 * * *$ & $-0.24 * * *$ & $0.04 * * *$ & $-0.34 * * *$ & $0.06 * * *$ & 1 & & & & \\
\hline 8. LEV & 0.274 & 0.474 & $0.55^{* * *}$ & $0.57^{* * *}$ & $0.23^{* * * *}$ & $0.14 * * *$ & $0.31^{* * *}$ & $0.13^{* * *}$ & $-0.04 * * *$ & 1 & & & \\
\hline 9. ACE & 0.535 & 0.516 & $-0.13 * * *$ & $-0.07 * * *$ & 0.55 *** & $-0.06^{* * * *}$ & $0.62 * * *$ & $-0.07^{* * *}$ & $-0.39 * * *$ & $0.22 * * *$ & 1 & & \\
\hline 10. FS & 0.097 & 0.101 & $0.08 * * *$ & $0.10^{* * *}$ & $0.66 * * *$ & $-0.08 * * *$ & $0.56^{* * *}$ & $-0.09 * * *$ & $-0.17 * * *$ & $0.46^{* * *}$ & $0.40^{* * *}$ & 1 & \\
\hline 11. PPE & 0.634 & 0.616 & $0.79 * * *$ & $0.77 * * *$ & 0.12 *** & $0.22 * * *$ & $0.25 * * *$ & $0.22 * * *$ & $-0.006 * *$ & $0.67 * * *$ & $0.12 * * *$ & $0.04 * * *$ & 1 \\
\hline
\end{tabular}

\section{Results and Discussion}

\subsection{Descriptive Statistics and Correlations}

Table 3 reveals the descriptive statistics and correlation results with 1609 observations.

Table 3. Descriptive statistics and correlations.

Note: Significance level: ${ }^{* *} p<0.05,{ }^{* * *} p<0.01 ; \mathrm{M}$ and SD stand for mean and standard deviation respectively.

\subsection{Endogeneity Analysis}

Panel data have been used for this examination, and they are normally associated with the endogeneity issue [113]. The endogeneity problem refers to the situation when independent variables correlate with error terms during regression, which may in turn cause unreliable and biased outcomes [145]. Two major causes make explanatory variables endogenous [130]: firstly, when equations are regressed, the causality arises in both methods even from explanatory to dependent variables or vice versa; and secondly, although explanatory and dependent variables do not have a direct effect, few other variables are responsible in creating a correlation between them. Therefore, we conducted the test for endogeneity by employing the Ordinary Least Square (OLS) regression and Wald-Test [146,147]. Our main models have ROA and TQ as dependent variables, and each independent variable of 
$\mathrm{AC} 1, \mathrm{AC} 2, \mathrm{CEO}$ Power, OC, and interaction terms is therefore replaced with the dependent variable and created residuals to check for endogeneity bias. The significance level of the created residuals of each independent variable confirms the endogeneity issue, but for better validity, we conducted a Wald test, which resulted in further confirmation that there is endogeneity in our panel data $[146,147]$. Our endogeneity test results confirmed the correlation between residuals and explanatory variables. Next, we estimated the residuals by applying the Wald test to check the significance level of the created residuals of each independent variable. These revealed that they are endogenously biased. For instance, RESID_AC2 is $0.038(p$-value $=1 \%)$; RESID_AC2 is $0.094(p$-value $=1 \%)$; RESID_CEOPOWER is 0.064 $(p$-value $=1 \%)$; RESID_OC is $0.333(p$-value $=1 \%)$; RESID_CEOAC1 is $0.126(p$-value $=1 \%)$; RESID_CEOAC2 is $0.123(p$-value $=1 \%)$; RESID_OCAC1 is $0.065(p$-value $=1 \%)$; and RESID_OCAC2 is 0.025 ( $p$-value $=1 \%$ ). Our results confirmed the presence of correlation between explanatory variables and residuals. According to the rule of econometrics, if one variable is found endogenous in the model, there is then a need to apply suitable statistical approaches to remove or minimize the endogeneity effects [148]. Table 4 shows the significance level of the residuals and F-values of the Wald test.

Table 4. Results of the endogeneity test.

\begin{tabular}{|c|c|c|c|c|c|c|c|c|}
\hline \multirow{2}{*}{$\begin{array}{l}\text { Independent } \\
\text { Variables }\end{array}$} & \multicolumn{8}{|c|}{ OLS } \\
\hline & Mo & 11 & Model 2 & Model 3 & Model 4 & Model 5 & Model 6 & Model 7 \\
\hline RESID_AC1 & $0.038^{* * *}$ & & & & & & & \\
\hline RESID_AC2 & & $0.094^{* * *}$ & & & & & & \\
\hline RESID_CEOPOWER & & & $0.064^{* * *}$ & & & & & \\
\hline RESID_OC & & & & $0.333^{* * *}$ & & & & \\
\hline RESID_CEOAC1 & & & & & $0.126^{* * *}$ & & & \\
\hline RESID_CEOAC2 & & & & & & $0.123 * * *$ & & \\
\hline RESID_OCAC1 & & & & & & & $0.065^{* * *}$ & \\
\hline RESID_OCAC2 & & & & & & & & $0.025 * * *$ \\
\hline ATO & $0.003^{* * *}$ & $0.004^{* * *}$ & $0.003^{* * *}$ & $0.004^{* * *}$ & $0.002 * * *$ & $0.003^{* * *}$ & $-0.001 * *$ & $-0.001 * * *$ \\
\hline LEV & 0.007 & 0.012 & 0.007 & 0.008 & 0.008 & $-0.180^{* * *}$ & $-0.002^{* * *}$ & 0.002 \\
\hline $\mathrm{ACE}$ & $-0.157^{* * *}$ & $-0.149^{* * *}$ & $-0.154^{* * *}$ & $-0.155^{* * *}$ & $-0.167^{* * *}$ & $-0.151^{* * *}$ & $-0.069 * * *$ & $-0.024^{* * *}$ \\
\hline FS & $0.101^{* * *}$ & 0.026 & $0.083 * *$ & $0.084 * *$ & $-0.524 * * *$ & $-0.121 * *$ & $0.030 * * *$ & -0.001 \\
\hline PPE & $0.222 * * *$ & $0.221 * * *$ & $0.224 * * *$ & $0.225^{* * *}$ & $0.210 * * *$ & $0.222 * * *$ & $0.094^{* * *}$ & $0.055^{* * *}$ \\
\hline Constant & $0.068^{* * *}$ & $0.028 *$ & $0.069 * * *$ & $0.067^{* * *}$ & $-0.043^{* *}$ & -0.009 & $0.023^{* * *}$ & $0.013^{* * *}$ \\
\hline $\mathrm{R}^{2}$ & 0.8726 & 0.8725 & 0.8702 & 0.8705 & 0.8784 & 0.8784 & 0.9888 & 0.9569 \\
\hline $\begin{array}{l}\text { Wald Test } \\
\text { F-statistics }\end{array}$ & $23.14^{* * *}$ & $28.56^{* * *}$ & $13.10^{* * *}$ & $16.60^{* * *}$ & $6.07^{* *}$ & $48.97^{* * *}$ & $12.32 * * *$ & $42.68^{* * *}$ \\
\hline
\end{tabular}

Note: Significance level: ${ }^{*} p<0.1,{ }^{* *} p<0.05,{ }^{* * *} p<0.01 . ;$ OLS stands for ordinary least squares (OLS).

\subsection{Testing of Hypothesis 1}

Table 5 presents the coefficient values for each model to show the regression results, and the $p$-value represents the significance level. Model 1 of ROA shows that the coefficient value of $\mathrm{AC}_{1}$ is 0.037 ( $p$-value $=5 \%$ ) estimated with the fixed effect model, which means that the economic significance of $\mathrm{AC}_{1}$ could enhance the ROA by 0.037 points. When $\mathrm{AC}_{2}$ is $0.091(p$-value $=1 \%)$, it means that the economic significance of $\mathrm{AC}_{2}$ could enhance the ROA by 0.091 points. The Hausman test value is 14.31 ( $p$-value $=5 \%)$, which confirms the usage of a fixed effect model rather than the random effect model. Similarly, Model 1 of ROA shows that the coefficient value of $A_{1}$ is $0.039(p$-value $=1 \%)$ estimated with GMM model; it also shows that the economic significance of $\mathrm{AC}_{1}$ could enhance ROA by 0.039 points. $\mathrm{AC}_{2}$ is 0.053 ( $p$-value $=1 \%$ ) implies that the economic significance of $\mathrm{AC}_{2}$ could enhance the ROA by 0.053 points. On the other hand, Model 2 of Tobin's $\mathrm{Q}$ shows that the coefficient value of $\mathrm{AC}_{1}$ is 0.008 ( $p$-value $=1 \%$ ) estimated with the fixed effect model. This means that the economic significance of $\mathrm{AC}_{1}$ could enhance the TQ by 0.008 points, and when the coefficient value of $\mathrm{AC}_{2}$ is $0.022(p$-value $=1 \%)$, it means that the economic significance of $\mathrm{AC}_{2}$ could enhance the TQ by 0.022 points. The Hausman test value is 182.58 ( $p$-value $=1 \%$ ), which also supports the usage of the fixed effect model. Furthermore, Model 2 of Tobin's $Q$ shows that the coefficient value of $A C_{1}$ 
is 0.009 ( $p$-value $=1 \%$ ) estimated with GMM model, and this suggests that the economic significance of $\mathrm{AC}_{1}$ could enhance the TQ by 0.009 points. When the coefficient value of $\mathrm{AC}_{2}$ is 0.011 ( $p$-value $=5 \%$ ), it highlights that the economic significance of $\mathrm{AC}_{2}$ could enhance the TQ by 0.011 points. Thus, we fail to reject Hypothesis 1, which proposed that the AC has a significant positive connection with firm performance.

\subsection{Testing of Hypothesis 2}

Table 5 also presents the regression results for the association between CEO Power and firm performance. Model 3 of ROA reports that the coefficient value of CEO Power is $0.063(p$-value $=1 \%$ ) estimated with the fixed effect model; the economic significance of CEO Power could enhance the ROA by 0.063 points. The Hausman test value is 63.47 ( $p$-value $=1 \%$ ), which allows using the fixed effect model despite the random effect model. Similarly, Model 3 of ROA reports that the coefficient value of CEO Power is $0.094(p$-value $=1 \%$ ) estimated with the GMM model, which also reveals that the economic significance of CEO Power could enhance ROA by 0.094 points. Furthermore, Model 5 of Tobin's Q reports that the coefficient value of CEO Power is $0.011(p$-value $=1 \%$ ) estimated with the fixed effect model and highlights that the economic significance of CEO Power could enhance TQ by 0.011 points. The Hausman test value is 81.33 ( $p$-value $=1 \%$, which supports the fixed effect. Additionally, Model 4 of Tobin's Q reports that the coefficient value of CEO Power with the GMM model is 0.023 ( $p$-value $=1 \%$ ), which shows that the economic significance of CEO Power could enhance the TQ by 0.023 points. Based on these results, we have also failed to reject Hypothesis 2, which suggests that CEO Power and firm performance are significantly positively associated with each other.

\subsection{Testing of Hypothesis 3}

Table 5 presents the regression results for the association between ownership concentration and firm performance. Model 5 of ROA reports that the coefficient value of ownership concentration with fixed effect model is 0.325 ( $p$-value $=1 \%$ ), which reveals that the economic significance of ownership concentration could enhance the ROA by 0.325 points. The Hausman test value is $102.06(p$-value $=1 \%)$, which allows the usage of the fixed effect model despite the random effect model. Similarly, Model 5 of ROA reports that the coefficient value of ownership concentration with the GMM model is 0.217 ( $p$-value $=5 \%$, and these results present that the economic significance of ownership concentration could enhance the ROA by 0.217 points. Moreover, Model 6 of Tobin's Q reports that the coefficient value of ownership concentration with the fixed effect model is 0.079 ( $p$-value $=1 \%)$, which postulates that the economic significance of ownership concentration could enhance the TQ by 0.079 points. The Hausman test value is $209.30(p$-value $=1 \%)$, which supports the usage of the fixed effect model. Additionally, Model 6 of Tobin's $Q$ reports that the coefficient value of ownership concentration with the GMM model is 0.041 $(p$-value $=10 \%)$. This highlights that the economic significance of ownership concentration could enhance the TQ by 0.041 points. Based on these results, we fail to reject Hypothesis 3 , which postulates that $\mathrm{OC}$ and firm performance are significantly and positively attached.

\subsection{Testing of Hypotheses 4 and 5}

Table 6 reports the results about the association between the AC and firm performance with the moderating effects of CEO power and ownership concentration. Model 7 of ROA shows that the coefficient value of CEOAC1 Power with the fixed effect model is 0.129 ( $p$-value $=1 \%)$, which reveals that the economic significance of CEOAC1 could enhance the ROA by 0.129 points, and the coefficient value of CEOAC2 Power is 0.121 ( $p$-value $=1 \%$ ), which presents that the economic significance of CEOAC2 could enhance the ROA by 0.121 points. The Hausman test value is $28.23(p$-value $=1 \%)$. This confirms the usage of the fixed effect model rather than the random effect model. Similarly, Model 7 of ROA shows that the coefficient value of CEOAC1 with GMM model is 0.214 ( $p$-value $=1 \%$ ), which reveals that the economic significance of CEOAC1 is that it could enhance ROA by 0.214 points, 
and the coefficient value of CEOAC2 is 0.163 ( $p$-value $=1 \%$ ); it explains that the economic significance of CEOAC2 could enhance the ROA by 0.163 points with the GMM model. On the other hand, Model 8 of Tobin's Q shows that the coefficient value of CEOAC1 with the fixed effect model is $0.042(p$-value $=1 \%)$ and reveals that the economic significance of CEOAC1 could enhance the TQ by 0.042 points. As the coefficient value of CEOAC2 is $0.036(p$-value $=1 \%)$, it is revealed that the economic significance of CEOAC2 could enhance the TQ by 0.036 points with the fixed effect model. The Hausman test value is $27.80(p$-value $=1 \%)$, which also supports the usage of the fixed effect model. Furthermore, Model 8 of Tobin's Q shows that the coefficient value of CEOAC1 with GMM model is 0.062 $(p$-value $=1 \%)$, and this result shows that the economic significance of CEOAC1 could enhance the TQ by 0.062 points. The coefficient value of CEOAC2 is 0.048 ( $p$-value $=1 \%)$, which also explains that the economic significance of CEOAC2 could enhance the TQ by 0.048 points with the GMM model. Based on these results, we have failed to reject Hypothesis 4, which postulates that a powerful CEO significantly moderates the positive relationship between the audit committee and firm performance.

Table 6 reports the results of the association between the AC and firm performance with the moderating effect of ownership concentration. Model 9 of ROA shows that the coefficient value of OCAC1 with the fixed effect model is 0.064 ( $p$-value $=1 \%$, which presents that the economic significance of OCAC1 could enhance the ROA by 0.064 points, and when the coefficient value of OCAC2 Power is 0.025 ( $p$-value $=1 \%$ ), it highlights that the economic significance of OCAC2 could enhance the ROA by 0.025 points with the fixed effect model. The Hausman test value is $91.66(p$-value $=1 \%)$, which confirms the usage of the fixed effect model rather than the random effect model. Similarly, Model 9 of ROA shows that the coefficient value of OCAC1 with the GMM model is 0.065 ( $p$-value $=1 \%$ ) and explains that the economic significance of OCAC1 could enhance the ROA by 0.065 points. When the OCAC2 is $0.027(p$-value $=1 \%)$, it is presented that the economic significance of OCAC2 could enhance the ROA by 0.027 points with the GMM model. On the other hand, Model 10 of Tobin's Q shows that the coefficient value of OCAC1 with the fixed effect model is 0.012 ( $p$-value $=1 \%$ ) and thus reveals that the economic significance of OCAC1 could enhance the TQ by 0.012 points. When the coefficient value of OCAC2 is $0.010(p$-value $=1 \%)$, the economic significance of OCAC2 could then enhance the TQ by 0.010 points with the fixed effect model. The Hausman test value is $9.49(p$-value $=10 \%)$, which also supports the usage of the fixed effect model. Furthermore, Model 10 of Tobin's $Q$ shows that the coefficient value of OCAC1 with the GMM model is 0.013 ( $p$-value $=1 \%$ ), and therefore, the economic significance of OCAC1 enhances the TQ by 0.013 points, and when the coefficient value of OCAC2 is $0.009(p$-value $=1 \%)$, it also highlights that the economic significance of OCAC2 could enhance the TQ by 0.009 points with the GMM model. Based on these findings, we are unable to reject Hypothesis 5, which states that the $\mathrm{AC}$ and firm performance have a positive connection with the interaction of OC.

\subsection{Robustness Test}

To find more robust results, this study replaced the dependent variable with a different measure: earning per share (EPS), based on prior studies $[149,150]$. Heteroskedasticity normally occurs in the dataset when the variables' standard errors have observations over a particular amount of time which is not constant [151]. Heteroskedasticity generally appears in two circumstances such as conditional and unconditional situations. Conditional situation can be explained as the availability of variable volatility that leads to the future time of low and high volatility, whereas unconditional situation refers to a position where the future time of low and high volatility can be recognized. The predicted variable variance is not equal, and therefore, the OLS evaluator may be statistically inefficient and significant, which creates ambiguous inferences of the evaluator. According to researchers, the Feasible Generalized Least Square (FGLS) is a suitable technique to solve the above-mentioned issues from the data [152,153]. 
Table 5. Results of association between AC and firm performance and CEO power and firm performance and OC and firm performance.

\begin{tabular}{|c|c|c|c|c|c|c|c|c|c|c|c|c|}
\hline \multirow{3}{*}{$\begin{array}{c}\text { Independent } \\
\text { Variables }\end{array}$} & \multicolumn{2}{|c|}{ Model 1} & \multicolumn{2}{|c|}{ Model 2} & \multicolumn{2}{|c|}{ Model 3} & \multicolumn{2}{|c|}{ Model 4} & \multicolumn{2}{|c|}{ Model 5} & \multicolumn{2}{|c|}{ Model 6} \\
\hline & \multicolumn{2}{|c|}{ ROA } & \multicolumn{2}{|c|}{ TQ } & \multicolumn{2}{|c|}{ ROA } & \multicolumn{2}{|c|}{ TQ } & \multicolumn{2}{|c|}{ ROA } & \multicolumn{2}{|c|}{ TQ } \\
\hline & FE & GMM & FE & GMM & FE & GMM & FE & GMM & FE & GMM & FE & GMM \\
\hline $\mathrm{AC}_{1}$ & $0.037^{* *}$ & $0.039 * * *$ & $0.008^{* * *}$ & $0.009 * * *$ & & & & & & & & \\
\hline $\mathrm{AC}_{2}$ & $0.091^{* * *}$ & $0.053^{* * *}$ & $0.022 * * *$ & $0.011^{* *}$ & & & & & & & & \\
\hline CEO POWER & & & & & $0.063^{* * *}$ & $0.094^{* * *}$ & $0.011^{* * *}$ & $0.023^{* * *}$ & & & & \\
\hline OC & & & & & & & & & $0.325^{* * *}$ & $0.217^{* *}$ & $0.079 * * *$ & $0.041 *$ \\
\hline \multicolumn{13}{|l|}{ OCAC1 } \\
\hline \multicolumn{13}{|l|}{ OCAC2 } \\
\hline ATO & $0.004^{* * *}$ & $0.001^{* *}$ & $0.001^{* * *}$ & $0.001^{* * *}$ & $0.004^{* * *}$ & $0.001 *$ & $0.001^{* * *}$ & $0.001^{* * *}$ & $0.004^{* * *}$ & $0.002 * * *$ & $0.008^{* * *}$ & $0.001^{* * *}$ \\
\hline LEV & 0.013 & -0.003 & $0.005^{* * *}$ & 0.002 & 0.013 & $0.003^{* *}$ & $0.005^{* * *}$ & 0.002 & 0.007 & -0.007 & $0.004^{* *}$ & 0.011 \\
\hline $\mathrm{ACE}$ & $-0.151^{* * *}$ & $-0.187^{* * *}$ & $-0.033^{* * *}$ & $-0.042^{* * *}$ & $-0.149^{* * *}$ & $0.188^{* * *}$ & $-0.033^{* * *}$ & $-0.042^{* * *}$ & $-0.155^{* * *}$ & $-0.183^{* * *}$ & $-0.034^{* * *}$ & $0.041^{* * *}$ \\
\hline FS & $0.026^{*}$ & $0.143^{* *}$ & 0.002 & 0.024 & 0.025 & $0.137^{* *}$ & 0.002 & 0.023 & $0.098^{* *}$ & $0.226^{* * *}$ & $0.017^{*}$ & $0.044^{* * *}$ \\
\hline PPE & $0.219 * * *$ & $0.249 * * *$ & $0.045^{* * *}$ & $0.052 * * *$ & $0.224^{* * *}$ & $0.250 * * *$ & $0.046^{* * *}$ & $0.052^{* * *}$ & $0.224^{* * *}$ & $0.249 * * *$ & $0.046^{* * *}$ & $0.052 * * *$ \\
\hline Constant & 0.008 * & 0.026 & $0.003^{* *}$ & $0.009 *$ & 0.026 * & $0.026^{* *}$ & $0.005^{* * *}$ & 0.010 * & $0.066^{* * *}$ & $0.028 *$ & $0.013 * * *$ & 0.004 \\
\hline $\mathrm{F}$ & $10.66^{* * *}$ & & $13.93^{* * *}$ & & $9.44^{* * *}$ & & $11.79^{* * *}$ & & $12.44^{* * *}$ & & $16.21^{* * *}$ & \\
\hline $\mathrm{N}$ & 1617 & 1320 & 1617 & 1320 & 1617 & 1320 & 1617 & 1320 & 1617 & 1320 & 1617 & 1320 \\
\hline Hausman Test & $14.31^{* *}$ & & $182.58^{* * *}$ & & $63.47^{* * *}$ & & $81.33^{* * *}$ & & $102.06^{* * *}$ & & $209.30 * * *$ & \\
\hline Wald Chi ${ }^{2}$ & & $2973.10^{* * *}$ & & $2521.15^{* * *}$ & & $2935.13^{* * *}$ & & $2493.31^{* * *}$ & & $2951.75^{* * *}$ & & $2497.05^{* * *}$ \\
\hline
\end{tabular}

Note: Significance level: ${ }^{*} p<0.1,{ }^{* *} p<0.05,{ }^{* * *} p<0.01$. FE and GMM stand for fixed effect and generalized method of moments respectively. 
Table 6. Results of the association between AC and firm performance with the moderating effect of CEO power and OC.

\begin{tabular}{|c|c|c|c|c|c|c|c|c|}
\hline \multirow{3}{*}{$\begin{array}{l}\text { Independent } \\
\text { Variables }\end{array}$} & \multicolumn{2}{|c|}{ Model 7} & \multicolumn{2}{|c|}{ Model 8} & \multicolumn{2}{|c|}{ Model 9} & \multicolumn{2}{|c|}{ Model 10} \\
\hline & \multicolumn{2}{|c|}{ ROA } & \multicolumn{2}{|c|}{ TQ } & \multicolumn{2}{|c|}{ ROA } & \multicolumn{2}{|c|}{ TQ } \\
\hline & FE & GMM & FE & GMM & FE & GMM & FE & GMM \\
\hline $\mathrm{AC}_{1}$ & 0.012 & -0.030 & 0.011 & -0.004 & 0.045 ** & $0.005 *$ & -0.003 & 0.001 * \\
\hline $\mathrm{AC}_{2}$ & $0.110^{* * *}$ & $0.065^{* * *}$ & $0.026^{* * *}$ & $0.014^{* * *}$ & $-0.408^{* * *}$ & $-0.425^{* * *}$ & 0.029 * & 0.019 \\
\hline $\begin{array}{c}\text { CEO } \\
\text { POWER }\end{array}$ & $0.163^{* * *}$ & $0.288^{* * *}$ & 0.024 & $0.069^{* * *}$ & & & & \\
\hline OC & & & & & $2.046^{* * *}$ & $2.120^{* * *}$ & 0.128 ** & -0.088 \\
\hline CEOAC1 & $0.129 * * *$ & $0.214^{* * *}$ & $0.042^{* * *}$ & $0.062^{* * *}$ & & & & \\
\hline CEOAC2 & 0.121 *** & $0.163^{* * *}$ & $0.036^{* * *}$ & $0.048^{* * *}$ & & & & \\
\hline OCAC1 & & & & & $0.064 * * *$ & $0.065^{* * *}$ & $0.012 * * *$ & $0.013^{* * *}$ \\
\hline OCAC2 & & & & & $0.025^{* * *}$ & $0.027^{* * *}$ & $0.010^{* * *}$ & $0.009^{* * *}$ \\
\hline ATO & $0.002 * * *$ & 0.001 & $0.007^{* * *}$ & $0.003 * *$ & $0.001^{* * *}$ & $-0.009 * * *$ & -0.003 & -0.006 \\
\hline LEV & $-0.126^{* * *}$ & $-0.230^{* * *}$ & $-0.041^{* * *}$ & $-0.065^{* * *}$ & 0.002 & -0.002 & $0.001^{* * *}$ & $0.002^{* * *}$ \\
\hline $\mathrm{ACE}$ & $-0.167^{* * *}$ & $-0.196^{* * *}$ & $-0.037^{* * *}$ & $0.044^{* * *}$ & $0.031^{* * *}$ & $0.046^{* * *}$ & $-0.006^{* * *}$ & $-0.009 * * *$ \\
\hline FS & $0.579 * * *$ & $0.641 * * *$ & $-0.181 * * *$ & $0.209^{* * *}$ & 0.004 & 0.018 & 0.004 * & $0.007^{* * *}$ \\
\hline PPE & $0.219^{* * *}$ & $0.251^{* * *}$ & $0.044^{* * *}$ & $0.052 * * *$ & $0.058^{* * *}$ & $0.057^{* * *}$ & $0.008^{* * *}$ & \\
\hline Constant & $0.051 * * *$ & $0.107^{* * *}$ & $0.017^{* * *}$ & $0.033^{* * *}$ & $0.016^{* * *}$ & $0.026^{* * *}$ & $0.036^{* * *}$ & $0.004 * *$ \\
\hline$R^{2}$ & 0.7001 & & 0.6683 & & 0.9725 & & 0.9735 & \\
\hline $\mathrm{F}$ & $8.71 * * *$ & & $11.05^{* * *}$ & & $18.09^{* * *}$ & & $22.86^{* * *}$ & \\
\hline $\mathrm{N}$ & 1615 & 1320 & 1615 & 1302 & 1615 & 1320 & 1615 & 1320 \\
\hline $\begin{array}{c}\text { Hausman } \\
\text { Test }\end{array}$ & $28.23 * * *$ & & $27.80^{* * *}$ & & $91.66^{* * *}$ & & $9.49 *$ & \\
\hline Wald $\mathrm{Chi}^{2}$ & & $3270.48^{* * *}$ & & $2948.59^{* * *}$ & & $49,681 \cdot 24^{* * *}$ & & $47,962.33^{* * *}$ \\
\hline
\end{tabular}

Note: Significance level: ${ }^{*} p<0.1,{ }^{* *} p<0.05,{ }^{* * *} p<0.01$. FE and GMM stand for fixed effect and generalized method of moments respectively.

Because this study used firm-level panel data, there is therefore a need to control the heteroskedasticity and autocorrelation problems. Wooldridge [152] and Baltagi [154] provided a test of serial autocorrelation between residuals over a specified period of time with the use of FGLS model. They suggested that the FGLS model can make the autocorrelation robust in order to evaluate the parameters in the equation. Greene [153] contended that FGLS model is the best method to reduce the possibility of heteroskedasticity in the panel and cross-sectional data. Furthermore, multiple studies recommended that autocorrelation and heteroskedasticity problems can be overcome by using FGLS [154-157]. Hence, we applied the FGLS model as a robustness test to overcome these issues from the panel data and further validate the results.

Table 7 presents Models 1 to 5, which show that the coefficient values with the FGLS model. Model 1 reports that the coefficient values of $\mathrm{AC}_{1}$ and $\mathrm{AC}_{2}$ are 0.022 and 0.066 , respectively, with $1 \%$ significance level. These outcomes also support the first hypothesis. In addition to that, Model 2 reveals that the coefficient value of CEO power is 0.056 at $1 \%$ significance level, which also contends with our second hypothesis. In addition to that, Model 3 reports that the coefficient value of OC is 0.225 at $1 \%$ significance level. These outcomes also confirm the third hypothesis. On the other hand, Model 4 shows that the coefficient value of $\mathrm{AC}_{1}{ }^{*} \mathrm{CEO}$ power is 0.026 , with a significance level at $10 \%$, and the coefficient value of $\mathrm{AC}_{2}{ }^{*} \mathrm{CEO}$ power is 0.017 , which has a significance level at $1 \%$. Thus, the results of the moderating effects of $\mathrm{CEO}$ power are also identical with prior findings. Lastly, Model 5 reveals that the coefficient value of $\mathrm{AC}_{1}{ }^{*} \mathrm{OC}$ is 0.017 and the significance level is $1 \%$, while the coefficient value of $\mathrm{AC}_{2}{ }^{*} \mathrm{OC}$ is 0.039 and the significance level $1 \%$. Therefore, these findings support our fifth hypothesis. However, all of our hypotheses are supported by the robustness test, which endorses the accuracy of the results. 
Table 7. Results of the robustness test.

\begin{tabular}{|c|c|c|c|c|c|}
\hline $\begin{array}{l}\text { Dependent } \\
\text { Variables }\end{array}$ & & & EPS & & \\
\hline \multirow{2}{*}{$\begin{array}{l}\text { Independent } \\
\text { Variables }\end{array}$} & \multicolumn{5}{|c|}{ FGLS } \\
\hline & Model 1 & Model 2 & Model 3 & Model 4 & Model 5 \\
\hline $\mathrm{AC}_{1}$ & $0.022^{* * *}$ & & & -0.011 & $0.018^{* * *}$ \\
\hline $\mathrm{AC}_{2}$ & $0.066^{* * *}$ & & & $0.060^{* * *}$ & $-0.165^{* * *}$ \\
\hline CEO Power & & $0.056^{* * *}$ & & $0.063^{* * *}$ & \\
\hline OC & & & $0.225^{* * *}$ & & $0.864^{* * *}$ \\
\hline CEOAC1 & & & & 0.026 * & \\
\hline CEOAC2 & & & & $0.017^{* * *}$ & \\
\hline OCAC1 & & & & & $0.017^{* * *}$ \\
\hline OCAC2 & & & & & $0.039^{* * *}$ \\
\hline ATO & 0.001 & $0.001^{* * *}$ & $-0.002^{* * *}$ & $0.004^{* * *}$ & $-0.001^{* * *}$ \\
\hline LEV & $0.042 * * *$ & $0.039 * * *$ & $0.017^{* * *}$ & 0.005 & $0.012^{* * *}$ \\
\hline ACE & $-0.037^{* * *}$ & $-0.041 * * *$ & $0.027^{* * *}$ & $-0.043^{* * *}$ & $0.002 * * *$ \\
\hline FS & $0.033^{* * *}$ & $-0.018^{* *}$ & $0.090^{* * *}$ & $-0.127^{* * *}$ & $-0.024^{* * *}$ \\
\hline PPE & $0.080^{* * *}$ & $0.081^{* * *}$ & $0.097^{* * *}$ & $0.082^{* * *}$ & $0.013^{* * *}$ \\
\hline Constant & $0.021^{* * *}$ & $0.023^{* * *}$ & $0.001 *$ & $0.024^{* * *}$ & $0.003^{* * *}$ \\
\hline $\mathrm{N}$ & 1615 & 1615 & 1615 & 1615 & 1615 \\
\hline Wald Chi ${ }^{2}$ & $7481.56^{* * *}$ & $6863.92 * * *$ & $8747.40 * * *$ & $7066.66^{* * *}$ & $45,947.83^{* * *}$ \\
\hline
\end{tabular}

Note: Significance level: ${ }^{*} p<0.1,{ }^{* *} p<0.05,{ }^{* * *} p<0.01$; FGLS stands for Feasible Generalized Least Square (FGLS).

\subsection{Discussion}

The first hypothesis proposes that an AC has a positive and significant relationship with firm performance, and the results of this study confirms the first hypothesis. To support these results, agency theory provided the evidence [20] as the establishment of an AC is a symbol of independence of financial reporting, which in turn enhances the shareholders' confidence. A developing economy such as Pakistan has a lack of trust from the shareholders; thus, an AC thus assures the shareholders of the transparency of all financial activities [42]. Kallamu and Saat [45] reported that independent directors in the AC provide strong and efficient monitoring, which is beneficial for firm financial performance. Transparent auditing practices enhance the shareholders' confidence, which may result in higher profitability.

The second hypothesis states that CEO power positively and significantly affects firm performance, and the results of this study also assures the second hypothesis. Various scholars have shown that firms of developing economies have a family member as the CEO $[26,158]$ who works hard to enhance firm performance. Moreover, the organizational and management theory and managerial power theory also support that a powerful CEO enhances firm performance by making wise decisions and controlling management. Firms within the Pakistani market have a higher ratio of family ownership, and the majority of the CEOs are family members. Therefore, every CEO looks for positive means to improve the business performance. Aside from that, a powerful CEO may have tight control over all organizational practices, which also leads to higher profitability.

The third hypothesis of this study reveals that OC and firm performance are positively connected. Similarly, the outcomes are identical with the third hypothesis, and the managerial power theory also supports these results [50]. Several researchers have contended that developing economies are connected with higher concentrated ownership [27,28]. Thus, ownership concentration plays a major role to overcome this issue in developing economies, where poor laws and regulations exist to protect shareholders' interests [73]. Generally, large shareholders have ownership rights, so owners are therefore always interested in business performance. Large shareholders support the organization's transparent and social practices for goodwill. They always think about the survival of firms in the long run.

The results of this study confirm the fourth hypothesis in which the AC and firm performance have a positive connection with the moderating effect of CEO Power. As 
firms of developing economies have CEOs as family members, a family member therefore always tries to enhance firm performance. The AC creates a firm's reputation and a good image in the view of shareholders, which in turn improves the confidence and trust of shareholders. The participation of corporate governance in the AC and other corporate decisions improves the overall firm performance, and the CEO is a major part of corporate governance [11,12]. A powerful CEO is valuable for creating transparency in auditing and other firm activities [15]. Lubatkin, Schulze, Ling and Dino [83] stated that a powerful CEO or family members of CEOs put pressure on the agents to reduce self-interest and work hard for the firm's performance. CEOs of firms remain fully aware of the reputation of firms for long-tern profit; therefore, they support the organization's transparent practices such as auditing quality. Our results have highlighted that auditing practices enhance a firm's performance, which means that CEOs from family ownership have more involvement in transparent practices.

Lastly, the results of our fifth hypothesis confirm that an AC and firm performance have a positive connection with ownership concentration. La Porta, Lopez-de-Silanes, Shleifer and Vishny [37] discovered that OC has much importance for firms to control and monitor financial matters and develop a proper AC. Previous studies explained that firms from developing economies are much more concentrated than developed economies [27]. Therefore, it is believed that the majority of shares held by family members force the AC to perform their task fairly and monitor the agents' actions. This practice reduces or minimizes the firm's fraudulent activities and tightens the AC for transparency, which ultimately captures the reputed image in the market. Furthermore, firms within developing economies have a want to enhance export ratio, which perceives the pressure of international rules and regulations to present accurate information. Mitra, Hossain and Deis [92] revealed that firms that hold higher ownership concentration have higher demands of the AC by shareholders. Ownership concentration plays a positive role in improving audit practices and business performance because large shareholders are always interested in the good reputation of the firm for higher profit.

\section{Conclusions}

Firms of developing economies generally face fraudulent and other illegal activities that damage the image of firms in the market. Firms that have the intent to enter the international market must adopt fair and transparent practices. Therefore, an AC is supposed to be a major body in monitoring fraudulent actions, and various scholars investigated the association between $\mathrm{AC}$ and firm performance with different outcomes [6,43-45]. However, these researchers have failed to shed light on the circumstances that develop a positive or negative connection between the AC and firm performance.

Based on this gap, the current study has placed a major focus on the analysis of the $\mathrm{AC}$ and firm performance with the moderating effect of CEO power and ownership concentration. This study focused on 147 Pakistani manufacturing firms from 2008 to 2018. Various research techniques have been employed in this study. First, we adopted OLS regression to identify the endogeneity issue in the panel dataset. Next, the fixed effect model was applied to control unobservable heterogeneity. Afterwards, the GMM model was employed to overcome endogeneity issues. Finally, this study also employed a robustness test, (the FGLS model) to deal with heterogeneity.

From the results, this study has revealed that an AC and firm performance have a positive connection, and these findings contend with previous studies [6,43-45]. In addition, the findings have shown that a powerful CEO and firm performance are positively connected, and these results are also supported by prior scholars [62,63]. Thus, the outcomes have presented that an OC and firm performance have a positive connection in line with previous studies conducted by $[68,69,72]$.

Next, the findings of this study have discovered that the interaction of CEO power has a positive influence on the association between $\mathrm{AC}$ and firm performance. For support, several researchers have argued that a powerful CEO forces $A C$ members to control 
fraudulent behaviors, which automatically enhances firm performance $[59,159]$. Lastly, the investigation of this study revealed that an AC and firm performance also have a positive connection with the moderating effect of the OC. To support these outcomes, multiple scholars have supported the positive influence of an OC on the AC and firm performance $[44,66]$.

\subsection{Policy Implications}

The outcomes of this study have multiple suggestions and implications for researchers, owners, managers, investors, policymakers, and governments of both developed and developing economies. This is the first study that has looked into the linkage between AC and firm performance with the moderating role of CEO power and OC. The outcomes of this study differentiate it from prior studies by motivating the top executives to improve firm performance. Transparency is a hot issue in developing economies, especially in Pakistan; therefore, this study promotes the role of top executives in improving transparency issues. Unlike prior literature in Pakistan, this study has combined a few imperative econometric techniques to acquire more accurate results such as FE, GMM, and FGLS. This study has shed light on the importance of an AC and its role in firm performance. Firms should focus on an independent $\mathrm{AC}$ in order to remove or minimize fraudulent activities and enhance their reputation. Owners of firms should also focus on improving audit activities by giving independence to auditors and appointing expert members in the AC. Most importantly, this study has highlighted the role of corporate governance in improving audit activities of firms.

The CEO is largely the responsible authority who influences audit activities, so this study suggests that the AC could be monitored and controlled by the CEO. Furthermore, this study suggests that ownership concentration is also an imperative means to improving audit activities. Executives and policymakers should focus on corporate governance issue while taking decisions to improve audit activities. In addition, governments of developing economies can also gain benefits by improving audit activities, which ultimately enhance firm performance. An improved firm performance is valuable for the economy of the country. The development of the industrial sector can play an imperative part in improving economic conditions. The transparency of the firms could be improved by the AC, and governments should compel firms to form an independent AC. As the outcomes of this study have proven that $\mathrm{CEO}$ and ownership concentration are valuable tools for an $\mathrm{AC}$ and firm performance, the government should therefore support and motivate governance issues for forming independent AC. This study is fruitful for researchers, as this study has focused on AC and corporate governance issues that can explore the efficiency and effectiveness of firms.

This study also suggests that the Government of Pakistan (GOP) focus on auditing for more transparency and enhancing shareholders' confidence. The SECP should apply strict regulations on firms when forming an AC. Furthermore, the SECP should strictly monitor the CEOs and large shareholders in forming an independent AC and disclose all financial and non-financial actions. Investors will feel safe when transparency and protection are available. By focusing on the results of this study, firms and governments can enhance shareholders' confidence and attract new investors. In addition, the outcomes of this study are constructive for industries and top executives to explore auditing issues in Pakistan.

The findings of this study are appropriate for both developing and developed economies firms that have the intention to work beyond the domestic market. Accurate auditing services may help to capture the long-term anticipated value in the context of good reputation, customer loyalty, investor confidence, and employee pleasure. This study is an important addition to the narrow literature on the role of top executives in the improvement of auditing in Pakistan and other countries. This study will motivate the CEOs, large shareholders, owners, and investors to contribute to auditing activities for a better performance of firms. 


\subsection{Limitations and Future Research}

For future research, selecting multiple countries and various sectors as a sample for this study could provide a meaningful insight into the existing literature. Moreover, other corporate governance entities such as the chief financial officer, managerial ownership, institutional and foreign owners, etc. can be taken into account to inspect auditing practices and firm performance.

Author Contributions: Conceptualization, writing—original draft preparation, S.A.J.; funding acquisition, supervision, T.S.O.; methodology, writing—review and editing, R.L.; formal analysis, W.N.S., data curation, H.M. All authors have read and agreed to the published version of the manuscript.

Funding: This research was funded by the Universiti Putra Malaysia.

Institutional Review Board Statement: Not applicable.

Informed Consent Statement: Not applicable.

Data Availability Statement: Not applicable.

Acknowledgments: The authors would like to acknowledge the comments and suggestions given by the anonymous reviewers that have significantly improved the quality of our work.

Conflicts of Interest: The authors declare that the research was conducted in the absence of any commercial or financial relationships that could be construed as a potential conflict of interest.

\section{References}

1. Waweru, N. Determinants of quality corporate governance in Sub-Saharan Africa. Manag. Audit. J. 2014, 29, 455-485. [CrossRef]

2. Khan, A.; Mihret, D.G.; Muttakin, M.; Management, I. Corporate political connections, agency costs and audit quality. Int. J. Account. Inf. Manag. 2016, 24, 357-374. [CrossRef]

3. Iyer, V.M.; Bamber, E.M.; Griffin, J. Characteristics of audit committee financial experts: An empirical study. Manag. Audit. J. 2013, 28, 65-78. [CrossRef]

4. Krishnan, J. Audit committee quality and internal control: An empirical analysis. Account. Rev. 2005, 80, 649-675. [CrossRef]

5. Hoitash, U.; Hoitash, R.; Bedard, J. Corporate governance and internal control over financial reporting: A comparison of regulatory regimes. Account. Rev. 2009, 84, 839-867. [CrossRef]

6. Aldamen, H.; Duncan, K.; Kelly, S.; McNamara, R.; Nagel, S. Audit committee characteristics and firm performance during the global financial crisis. Account. Financ. 2011, 52, 971-1000. [CrossRef]

7. Sattar, U.; Javeed, S.A.; Latief, R. How audit quality affects the firm performance with the moderating role of the product market competition: Empirical evidence from Pakistani manufacturing firms. Sustainability 2020, 12, 4153. [CrossRef]

8. Mohammed, B.H.; Flayyih, H.H.; Mohammed, Y.N.; Abbood, H.; Science, A. The effect of audit committee characteristics and firm financial performance: An empirical study of listed companies in Iraq stock exchange. J. Eng. Appl. Sci. 2019, 14, 4919-4926. [CrossRef]

9. Sulong, Z.; Gardner, J.C.; Hussin, A.H.; Mohd Sanusi, Z.; McGowan, C.B. Managerial ownership, leverage and audit quality impact on firm performance: Evidence from the Malaysian Ace Market. Account. Tax. 2013, 5, 59-70.

10. Zhou, H.; Owusu-Ansah, S.; Maggina, A. Board of directors, audit committee, and firm performance: Evidence from Greece. Int. Account. Audit. Tax. 2018, 31, 20-36. [CrossRef]

11. Beasley, M.S.; Carcello, J.V.; Hermanson, D.R.; Neal, T. The audit committee oversight process. Account. Res. 2009, 26, 65-122. [CrossRef]

12. Cohen, J.; Krishnamoorthy, G.; Wright, A.J. Corporate governance in the post-Sarbanes-Oxley era: Auditors' experiences. Account. Res. 2010, 27, 751-786. [CrossRef]

13. Carcello, J.V.; Neal, T.L.; Palmrose, Z.V.; Scholz, S. CEO involvement in selecting board members, audit committee effectiveness, and restatements. Contemp. Account. Res. 2011, 28, 396-430. [CrossRef]

14. Bruynseels, L.; Cardinaels, E. The audit committee: Management watchdog or personal friend of the CEO? Account. Rev. 2014, 89, 113-145. [CrossRef]

15. Busenbark, J.R.; Krause, R.; Boivie, S.; Graffin, S. Toward a configurational perspective on the CEO: A review and synthesis of the management literature. J. Manag. 2016, 42, 234-268. [CrossRef]

16. Liu, X.; Lu, J.; Chizema, A. Top executive compensation, regional institutions and Chinese OFDI. J. World Bus. 2014, 49, 143-155. [CrossRef]

17. Shleifer, A.; Vishny, R.W. Survey of Corporate Governance. J. Financ. 1997, 2, 737-783. [CrossRef]

18. Hill, C.W.; Jones, T.M. Stakeholder-agency theory. J. Manag. Stud. 1992, 29, 131-154. [CrossRef]

19. Wiseman, R.M.; Cuevas-Rodríguez, G.; Gomez-Mejia, L.R. Towards a social theory of agency. J. Manag. Stud. 2011, 49, $202-222$. [CrossRef] 
20. Jensen, M.C.; Meckling, W.H. Theory of the firm: Managerial behavior, agency costs and ownership structure. J. Financ. Econ. 1976, 3, 305-360. [CrossRef]

21. Sah, R.; Stiglitz, J. The Architecture of Economic Systems: Hierarchies and Polyarchies. Am. Econ. Rev. 1984, 76, 716-727. [CrossRef]

22. Bebchuk, L.A.; Fried, J.M.; Walker, D.I. Managerial Power and Rent Extraction in The Design Of Executive Compensation; National Bureau of Economic Research: Cambridge, MA, USA, 2002; Volume 69, pp. 751-846.

23. Sheikh, S. CEO inside debt, market competition and corporate risk taking. Int. J. Manag. Financ. 2019, 15, 636-657. [CrossRef]

24. Waweru, N.M.; Kamau, R.G.; Uliana, E. Audit committees and corporate governance in a developing country. Int. J. Account. Audit. Perform. Eval. 2011, 7, 337-358. [CrossRef]

25. Tsamenyi, M.; Enninful-Adu, E.; Onumah, J. Disclosure and corporate governance in developing countries: Evidence from Ghana. Manag. Audit. J. 2007, 22, 319-334. [CrossRef]

26. Hussain, S. Ownership structure of family business groups of Pakistan. In Proceedings of the Economics and Finance Conferences, Rome, Italy, 10-13 September 2018; pp. 75-89. [CrossRef]

27. Dam, L.; Scholtens, B. Ownership concentration and CSR policy of European multinational enterprises. J. Bus. Ethics 2013, 118, 117-126. [CrossRef]

28. Castellaneta, F.; Gottschalg, O. Does ownership matter in private equity? The sources of variance in buyouts' performance. Strat. Manag. J. 2014, 37, 330-348. [CrossRef]

29. Siddiqui, J. Development of corporate governance regulations: The case of an emerging economy. J. Bus. Ethics 2010, 91, 253-274. [CrossRef]

30. Easterly, W. The Political Economy of Growth without Development: A Case Study of Pakistan; Kennedy School of Government, Harvard University: Cambridge, MA, USA, 2001; pp. 1-53.

31. Iqbal, J. Stock market in Pakistan: An overview. J. Emerg. Mark. Financ. 2012, 11, 61-91. [CrossRef]

32. Ibrahim, A. Corporate governance in Pakistan: Analysis of current challenges and recommendations for future reforms. Wash. Univ. Glob. Stud. Law Rev. 2006, 5, 323.

33. Shah, S.Z.A.; Butt, S.A. The impact of corporate governance on the cost of equity: Empirical evidence from Pakistani listed companies. Lahore J. Econ. 2009, 14, 139-171. [CrossRef]

34. Ashraf, J.; Ghani, W. Accounting development in Pakistan. Int. J. Account. 2005, 40, 175-201. [CrossRef]

35. Waheed, A. Securities E Exchange Commission of Pakistan and United Nations Development Program; United Nations: San Francisco, CA, USA, 2005.

36. Rustam, S.; Rashid, K.; Zaman, K. Retracted: The relationship between audit committees, compensation incentives and corporate audit fees in Pakistan. Econ. Model. 2013, 31, 697-716. [CrossRef]

37. La Porta, R.; Lopez-de-Silanes, F.; Shleifer, A.; Vishny, R. Legal determinants of external finance. J. Financ. 1997, 52, 1131-1150. [CrossRef]

38. Morck, R.; Shleifer, A.; Vishny, R. Management ownership and market valuation: An empirical analysis. J. Financ. Econ. 1988, 20, 293-315. [CrossRef]

39. Yusuf, F.; Yousaf, A.; Saeed, A. Rethinking agency theory in developing countries: A case study of Pakistan. Account. Forum 2018, 42, 281-292. [CrossRef]

40. Bonazzi, L.; Islam, S. Agency theory and corporate governance: A study of the effectiveness of board in their monitoring of the CEO. J. Model. Manag. 2007, 2, 7-23. [CrossRef]

41. Power, M. Evaluating the audit explosion. Law Policy 2003, 25, 185-202. [CrossRef]

42. Ghafran, C.; O'Sullivan, N. The governance role of audit committees: Reviewing a decade of evidence. Int. J. Manag. Rev. 2013, 15, 381-407. [CrossRef]

43. Chan, K.C.; Li, J. Audit committee and firm value: Evidence on outside top executives as expert-independent directors. Corp. Gov. Int. Rev. 2008, 16, 16-31. [CrossRef]

44. Arshad, M.A.; Satar, R.A.; Hussain, M.; Naseem, M.A. Effect of audit on profitability: A study of cement listed firms, Pakistan. Glob. J. Manag. Bus. Res. 2011, 11, 1-5.

45. Kallamu, B.S.; Saat, N. Audit committee attributes and firm performance: Evidence from Malaysian finance companies. Asian Rev. Account. 2015, 23, 206-231. [CrossRef]

46. Bansal, N.; Sharma, A.K. Audit committee, corporate governance and firm performance: Empirical evidence from India. Int. J. Econ. Financ. 2016, 8, 103. [CrossRef]

47. Hutchinson, M.R.; Zain, M. Internal audit quality, audit committee independence, growth opportunities and firm performance. Corp. Ownersh. Control 2009, 7, 50-63. [CrossRef]

48. Lin, J.W.; Hwang, M.I. Audit quality, corporate governance, and earnings management: A meta-analysis. Int. J. Audit. 2010, 14, 57-77. [CrossRef]

49. Chiu, J.; Chen, C.-H.; Cheng, C.-C.; Hung, S.-C. Knowledge capital, CEO power, and firm value: Evidence from the IT industry. N. Am. J. Econ. Financ. 2019, 101012. [CrossRef]

50. Bebchuk, L.A.; Fried, J.M. Executive compensation as an agency problem. J. Econ. Perspect. 2003, 17, 71-92. [CrossRef]

51. Faulkender, M.; Yang, J. Inside the black box: The role and composition of compensation peer groups. J. Financ. Econ. 2010, 96, 257-270. [CrossRef] 
52. Bebchuk, L.A.; Cremers, K.M.; Peyer, U.C. The CEO pay slice. J. Financ. Econ. 2011, 102, 199-221. [CrossRef]

53. Morse, A.; Nanda, V.; Seru, A. Are incentive contracts rigged by powerful CEOs? J. Financ. 2011, 66, 1779-1821. [CrossRef]

54. Landier, A.; Sauvagnat, J.; Sraer, D.; Thesmar, D. Bottom-up corporate governance. Rev. Financ. 2013, 17, 161-201. [CrossRef]

55. Brickley, J.A.; Coles, J.L.; Jarrell, G. Leadership structure: Separating the CEO and chairman of the board. J. Corp. Financ. 1997, 3, 189-220. [CrossRef]

56. Yang, T.; Zhao, S. CEO duality and firm performance: Evidence from an exogenous shock to the competitive environment. $J$. Bank. Financ. 2014, 49, 534-552. [CrossRef]

57. Berger, R.; Dutta, S.; Raffel, T.; Samuels, G. Innovating at the Top: How Global CEOs Drive Innovation for Growth and Profit; Palgrave Macmillan: London, UK, 2008.

58. Papadakis, V.M. Do CEOs shape the process of making strategic decisions? Evidence from Greece. Manag. Decis. 2006, 44, 367-394. [CrossRef]

59. Coles, J.L.; Li, Z.; Wang, A.Y. Industry tournament incentives. Rev. Financ. Stud. 2017, 31, 1418-1459. [CrossRef]

60. Javid, A.Y.; Iqbal, R. Ownership concentration, corporate governance and firm performance: Evidence from Pakistan. Pak. Dev. Rev. 2008, 47, 643-659. [CrossRef]

61. Kamran, K.; Shah, A. The impact of corporate governance and ownership structure on earnings management practices: Evidence from listed companies in Pakistan. Lahore J. Econ. 2014, 19, 27-70.

62. Bayless, M. The myth of executive compensation: Do shareholders get what they pay for? Appl. Financ. Econ. 2009, 19, 795-808. [CrossRef]

63. Buck, T.; Liu, X.; Skovoroda, R. Top executive pay and firm performance in China. J. Int. Bus. Stud. 2008, 39, 833-850. [CrossRef]

64. Setia-Atmaja, L.Y. Governance mechanisms and firm value: The impact of ownership concentration and dividends. Corp. Gov. Int. Rev. 2009, 17, 694-709. [CrossRef]

65. Baysinger, B.D.; Kosnik, R.D.; Turk, T.A. Effects of board and ownership structure on corporate R\&D strategy. Acad. Manag. J. 1991, 34, 205-214.

66. Berle, A.; Means, G.C. The Modern Corporation and Private Property; Transaction Publishers: Piscatawa, NJ, USA, 1932.

67. Butt, S.A.; Hasan, A. Impact of ownership structure and corporate governance on capital structure of Pakistani listed companies. Int. J. Bus. Manag. 2009, 4, 50-57.

68. Abbas, A.; Naqvi, H.A.; Mirza, H.H. Impact of large ownership on firm performance: A case of non financial listed companies of Pakistan. World Appl. Sci. J. 2013, 21, 1141-1152.

69. Peng, C.-W.; Yang, M.-L. The effect of corporate social performance on financial performance: The moderating effect of ownership concentration. J. Bus. Ethics 2014, 123, 171-182. [CrossRef]

70. Claessens, S.; Djankov, S.; Pohl, G. Ownership and corporate governance: Evidence from the Czech Republic; World Bank Publications: Washington, DC, USA, 1997.

71. Hanousek, J.; Kočenda, E.; Svejnar, J. Origin and concentration: Corporate ownership, control and performance in firms after privatization. Econ. Transit. 2007, 15, 1-31. [CrossRef]

72. Omran, M. Post-privatization corporate governance and firm performance: The role of private ownership concentration, identity and board composition. J. Comp. Econ. 2009, 37, 658-673. [CrossRef]

73. Kim, K.A.; Kitsabunnarat, P.; Nofsinger, J.R. Ownership and operating performance in an emerging market: Evidence from Thai IPO firms. J. Corp. Financ. 2004, 10, 355-381. [CrossRef]

74. Yasser, Q.R.; Mamun, A.A. The impact of ownership concentration on firm performance: Evidence from an emerging market. Emerg. Econ. Stud. 2017, 3, 34-53. [CrossRef]

75. Cohen, J.; Krishnamoorthy, G.; Wright, A.M. Corporate governance and the audit process. Contemp. Account. Res. 2002, 19, 573-594. [CrossRef]

76. Abbott, L.J.; Parker, S. Auditor selection and audit committee characteristics. Audit. J. Pract. Theory 2000, 19, 47-66. [CrossRef]

77. Boyd, B.K.; Haynes, K.T.; Zona, F. Dimensions of CEO-board relations. J. Manag. Stud. 2011, 48, 1892-1923. [CrossRef]

78. Ghosh, A.A.; Tang, C.Y. Assessing financial reporting quality of family firms: The auditors' perspective. J. Account. Econ. 2015, 60, 95-116. [CrossRef]

79. Srinidhi, B.N.; He, S.; Firth, M. The effect of governance on specialist auditor choice and audit fees in US family firms. Account. Rev. 2014, 89, 2297-2329. [CrossRef]

80. Chen, Y.; Gul, F.A.; Veeraraghavan, M.; Zolotoy, L. Executive equity risk-taking incentives and audit pricing. Account. Rev. 2015, 90, 2205-2234. [CrossRef]

81. Turley, S.; Zaman, M. Audit committee effectiveness: Informal processes and behavioural effects. Account. Audit. Account. J. 2007, 20, 765-788. [CrossRef]

82. Lubatkin, M.H.; Schulze, W.S.; Ling, Y.; Dino, R.N. The effects of parental altruism on the governance of family-managed firms. J. Organ. Behav. Int. J. Ind. Occup. Organ. Psychol. Behav. 2005, 26, 313-330.

83. Jizi, M.; Nehme, R. Board monitoring and audit fees: The moderating role of CEO/chair dual roles. Manag. Audit. J. 2018, 33, 217-243.

84. Karim, A.W.; van Zijl, T.; Mollah, S. Impact of board ownership, CEO-Chair duality and foreign equity participation on auditor quality choice of IPO companies. Int. J. Account. Inf. Manag. 2013, 21, 148-169. [CrossRef] 
85. Lisic, L.L.; Neal, T.L.; Zhang, I.X.; Zhang, Y. CEO power, internal control quality, and audit committee effectiveness in substance versus in form. Contemp. Account. Res. 2016, 33, 1199-1237. [CrossRef]

86. Kim, H.; Kwak, B.; Lim, Y.; Yu, J. Audit committee accounting expertise, CEO power, and audit pricing. Asia-Pac. J. Account. Econ. 2017, 24, 421-439.

87. Alzeban, A. The impact of audit committee, CEO, and external auditor quality on the quality of financial reporting. Corp. Gov. Int. J. Bus. Soc. 2019, 20, 263-279. [CrossRef]

88. Tee, C.M. CEO power and audit fees: Evidence from Malaysia. Int. J. Audit. 2019, 23, 365-386. [CrossRef]

89. Imhoff, E.A. Accounting quality, auditing and corporate governance. Account. Horiz. 2003, 17, 117-128. [CrossRef]

90. Watts, R.L.; Zimmerman, J.L. Agency problems, auditing, and the theory of the firm: Some evidence. J. Law Econ. 1983, 26, 613-633. [CrossRef]

91. Mitra, S.; Hossain, M.; Deis, D.R. The empirical relationship between ownership characteristics and audit fees. Rev. Quant. Financ. Account. 2007, 28, 257-285. [CrossRef]

92. Lin, Z.J.; Liu, M. The impact of corporate governance on auditor choice: Evidence from China. J. Int. Account. Audit. Tax. 2009, 18, 44-59. [CrossRef]

93. Fan, J.P.; Wong, T.J. Do external auditors perform a corporate governance role in emerging markets? Evidence from East Asia. J. Account. Res. 2005, 43, 35-72. [CrossRef]

94. Wahab, E.A.A.; Zain, M.M.; James, K. Political connections, corporate governance and audit fees in Malaysia. Manag. Audit. J. 2011, 26, 393-418. [CrossRef]

95. Mustapha, M.; Che Ahmad, A. Blockholders and corporate monitoring costs: Evidence from Malaysia. Int. J. Econ. Manag. 2013, $7,28-44$.

96. SECP. Rules and Regulations for Firms; SECP: Islamabad, Pakistan, 2013.

97. Javid, A.Y.; Iqbal, R.; Reports, R. Corporate Governance in Pakistan: Corporate Valuation, Ownership and Financing; PIDE Working Papers; Pakistan Institute of Development Economics: Islamabad, Pakistan, 2010; p. 57.

98. Javeed, S.A.; Lefen, L. An analysis of corporate social responsibility and firm performance with moderating effects of CEO power and ownership structure: A case study of the manufacturing sector of Pakistan. Sustainability 2019, 11, 248. [CrossRef]

99. SECP. Rules and Regulations for Firms; SECP: Islamabad, Pakistan, 2017.

100. World Bank. World Development Indicators; World Bank: Washington, DC, USA, 2016.

101. Ehsan, S.; Nazir, M.; Nurunnabi, M.; Raza Khan, Q.; Tahir, S.; Ahmed, I. A Multimethod Approach to Assess and Measure Corporate Social Responsibility Disclosure and Practices in a Developing Economy. Sustainability 2018, 10, 2955. [CrossRef]

102. Wang, Y.; Chui, A.C. Product market competition and audit fees. Audit. J. Pract. Theory 2014, 34, 139-156. [CrossRef]

103. Bhatti, M.I.; Awan, H.M. The role of quality auditing in the continuous improvement of quality: Lessons from Pakistani experience. Int. J. Audit. 2004, 8, 21-32. [CrossRef]

104. Awan, U.; Kraslawski, A.; Huiskonen, J. Understanding the relationship between stakeholder pressure and sustainability performance in manufacturing firms in Pakistan. Procedia Manuf. 2017, 11, 768-777. [CrossRef]

105. Rais, R.B.; Saeed, A. CMER Working Paper. In Regulatory Impact Assessment of SECP's Corporate Governance Code in Pakistan; Lahore University of Management Sciences: Lahore, Pakistan, 2005.

106. Moradi, M.; Velashani, M.A.B.; Omidfar, M. Corporate governance, product market competition and firm performance: Evidence from Iran. Humanomics 2017, 33, 38-55. [CrossRef]

107. Chiang, M.H.; Lin, J.H. The Relationship between Corporate Governance and Firm Productivity: Evidence from Taiwan's manufacturing firms. Corp. Gov. Int. Rev. 2007, 15, 768-779. [CrossRef]

108. Gill, A.S.; Biger, N.J. The impact of corporate governance on working capital management efficiency of American manufacturing firms. Manag. Financ. 2013, 39, 116-132. [CrossRef]

109. Florax, R.; Mulatu, A.; Withagen, C. Environmental regulation and competitiveness: A meta-analysis of international trade studies. In Empirical Modelling of the Economy and the Environment; Physica: Berlin/Heidelberg, Germany, 2003; Volume 20, pp. 53-73.

110. Kim, P.K.; Rasiah, D. Relationship between corporate governance and bank performance in Malaysia during the pre and post Asian financial crisis. Eur. J. Econ. Financ. Adm. Sci. 2010, 21, 39-63.

111. Shen, C.-H.; Wu, M.-W.; Chen, T.-H.; Fang, H. To engage or not to engage in corporate social responsibility: Empirical evidence from global banking sector. Econ. Model. 2016, 55, 207-225. [CrossRef]

112. Hutchinson, M.; Gul, F.A. Investment opportunity set, corporate governance practices and firm performance. J. Corp. Financ. 2004, 10, 595-614. [CrossRef]

113. Bhagat, S.; Bolton, B. Corporate governance and firm performance. J. Corp. Financ. 2008, 14, 257-273. [CrossRef]

114. Kumar, J. Does corporate governance influence firm value? Evidence from Indian firms. J. Entrep. Financ. 2004, 9, 61-91.

115. King, A.; Lenox, M. Exploring the locus of profitable pollution reduction. Manag. Sci. 2002, 48, 289-299. [CrossRef]

116. Horváthová, E. The impact of environmental performance on firm performance: Short-term costs and long-term benefits? Ecol. Econ. 2012, 84, 91-97. [CrossRef]

117. Ciftci, I.; Tatoglu, E.; Wood, G.; Demirbag, M.; Zaim, S. Corporate governance and firm performance in emerging markets: Evidence from Turkey. Int. Bus. Rev. 2019, 28, 90-103. [CrossRef] 
118. Wagner, M. The role of corporate sustainability performance for economic performance: A firm-level analysis of moderation effects. Ecol. Econ. 2010, 69, 1553-1560. [CrossRef]

119. Nazir, M.S.; Afza, T. Does managerial behavior of managing earnings mitigate the relationship between corporate governance and firm value? Evidence from an emerging market. Future Bus. J. 2018, 4, 139-156. [CrossRef]

120. Bhagat, S.; Black, B. The non-correlation between board independence and long-term firm performance. J. Corp. Law 2001, $27,231$. [CrossRef]

121. Arens, A.A.; Elder, R.J.; Mark, B. Auditing and Assurance Services: An Integrated Approach; Prentice Hall: Boston, MA, USA, 2012.

122. Hamdan, A.M.; Mushtaha, S.; Musleh Al-Sartawi, A. The audit committee characteristics and earnings quality: Evidence from Jordan. Australas. Account. Bus. Financ. J. 2013, 7. [CrossRef]

123. Finkelstein, S.; D'aveni, R.A. CEO duality as a double-edged sword: How boards of directors balance entrenchment avoidance and unity of command. Acad. Manag. J. 1994, 37, 1079-1108.

124. Hu, A.; Kumar, P. Managerial entrenchment and payout policy. J. Financ. Quant. Anal. 2004, 759-790. [CrossRef]

125. Singh, D.A.; Gaur, A.S. Business group affiliation, firm governance, and firm performance: Evidence from China and India. Corp. Gov. Int. Rev. 2009, 17, 411-425. [CrossRef]

126. Karaca, S.S.; Eksi, I.H. The relationship between ownership structure and firm performance: An empirical analysis over Istanbul Stock Exchange (ISE) listed companies. Int. Bus. Res. 2012, 5, 172. [CrossRef]

127. Dang, C.; Li, Z.F.; Yang, C.J. Measuring firm size in empirical corporate finance. J. Bank. Financ. 2018, 86, 159-176. [CrossRef]

128. Becker, T. Potential problems in the statistical control of variables in organizational research: A qualitative analysis with recommendations. Organ. Res. Methods 2005, 8, 274-289. [CrossRef]

129. Murphy, B.J. Selecting out of control variables with the T2 multivariate quality control procedure. J. R. Stat. Soc. D (Stat.) 1987, 36, 571-581.

130. Li, F. Endogeneity in CEO power: A survey and experiment. Invest. Anal. J. 2016, 45, 149-162. [CrossRef]

131. Li, Y.; Gong, M.; Zhang, X.-Y.; Koh, L. The impact of environmental, social, and governance disclosure on firm value: The role of CEO power. Br. Account. Rev. 2018, 50, 60-75. [CrossRef]

132. Al-Matari, E.M.; Al-Swidi, A.K.; Fadzil, F.H.B. Audit committee characteristics and executive committee characteristics and firm performance in Oman: Empirical study. Asian Soc. Sci. 2014, 10, 98.

133. Feng, Y.; Chen, H.H.; Tang, J. The Impacts of Social Responsibility and Ownership Structure on Sustainable Financial Development of China's Energy Industry. Sustainability 2018, 10, 301. [CrossRef]

134. Ibhagui, O.W.; Olokoyo, F.O. Leverage and firm performance: New evidence on the role of firm size. N. Am. J. Econ. Financ. 2018, 45, 57-82. [CrossRef]

135. Shah, S.Z.A.; Hussain, Z. Impact of ownership structure on firm performance evidence from non-financial listed companies at Karachi Stock Exchange. Int. Res. J. Financ. Econ. 2012, 84, 6-13.

136. Chen, S.; Sun, S.Y.; Wu, D. Client importance, institutional improvements, and audit quality in China: An office and individual auditor level analysis. Account. Rev. 2010, 85, 127-158. [CrossRef]

137. Kroes, J.R.; Manikas, A.S.; Gattiker, T.F. Operational leanness and retail firm performance since 1980. Int. J. Prod. Econ. 2018, 197, 262-274. [CrossRef]

138. Pepperberg, I.M. The Alex Studies: Cognitive and Communicative Abilities of Grey Parrots; Harvard University Press: Cambridge, MA, USA, 1999; p. 434.

139. Dittmar, A.; Mahrt-Smith, J. Corporate governance and the value of cash holdings. J. Financ. Econ. 2007, 83, 599-634. [CrossRef]

140. Antonakis, J.; Bendahan, S.; Jacquart, P.; Lalive, R. On making causal claims: A review and recommendations. Leadersh. Q. 2010, 21, 1086-1120.

141. Hamilton, B.H.; Nickerson, J.A. Correcting for endogeneity in strategic management research. Strateg. Organ. 2003, 1, 51-78. [CrossRef]

142. Beiner, S.; Drobetz, W.; Schmid, M.M.; Zimmermann, H.J. An integrated framework of corporate governance and firm valuation. Eur. Financ. Manag. 2006, 12, 249-283. [CrossRef]

143. Schultz, E.L.; Tan, D.T.; Walsh, K.D. Endogeneity and the corporate governance-performance relation. Aust. J. Manag. 2010, 35, 145-163. [CrossRef]

144. Wintoki, M.B.; Linck, J.S.; Netter, J.M. Endogeneity and the dynamics of internal corporate governance. J. Financ. Econ. 2012, 105, 581-606. [CrossRef]

145. Javeed, S.A.; Latief, R.; Lefen, L. An analysis of relationship between environmental regulations and firm performance with moderating effects of product market competition: Empirical evidence from Pakistan. J. Clean. Prod. 2020, 254, 120197. [CrossRef]

146. Wooldridge, J.M. Econometric Analysis of Cross Section and Panel Data; MIT Press: Cambridge, UK, 2010.

147. Semykina, A.; Wooldridge, J. Estimating panel data models in the presence of endogeneity and selection. J. Econom. 2010, 157, 375-380. [CrossRef]

148. Gujarati, D.N.; Porter, D.C.; Gunasekar, S. Basic Econometrics; Tata McGraw-Hill Education: New York, NY, USA, 2012.

149. Parket, I.R.; Eilbirt, H.J. The practice of business social responsibility: The underlying factors. Horizons 1975, 18, 5-10. [CrossRef]

150. Iwata, H.; Okada, K. How does environmental performance affect financial performance? Evidence from Japanese manufacturing firms. Ecol. Econ. 2011, 70, 1691-1700. [CrossRef]

151. Aitken, A.C. IV.-On least squares and linear combination of observations. Proc. R. Soc. Edinb. 1936, 55, 42-48. [CrossRef] 
152. Wooldridge, J. Inverse probability weighted M-estimators for sample selection, attrition, and stratification. Port. Econ. J. 2002, 1, 117-139. [CrossRef]

153. Greene, W. Estimating Econometric Models with Fixed Effects; Stern School of Business, New York University: New York, NY, USA, 2001.

154. Baltagi, B.H. Forecasting with panel data. J. Forecast. 2008, 27, 153-173. [CrossRef]

155. Chen, H.; Li, X.; Zeng, S.; Ma, H.; Lin, H. Does state capitalism matter in firm internationalization? Pace, rhythm, location choice, and product diversity. Manag. Decis. 2016, 54, 1320-1342. [CrossRef]

156. Mayur, M.; Saravanan, P. Performance implications of board size, composition and activity: Empirical evidence from the Indian banking sector. Corp. Gov. 2017, 17, 466-489. [CrossRef]

157. Singh, S.; Guha, M. Experiential learning: Analyzing success and failures in Indian telecom sector. Benchmarking Int. J. 2018, 25, 3702-3719. [CrossRef]

158. Ahmad, N.B.J.; Rashid, A.; Gow, J. Board independence and corporate social responsibility (CSR) reporting in Malaysia. Australas. Account. Bus. Financ. J. 2017, 11, 61-85. [CrossRef]

159. Wysocki, P. Corporate compensation policies and audit fees. J. Account. Econ. 2010, 49, 155-160. [CrossRef] 